\title{
Overexpression of the Type 1 Adenylyl Cyclase in the Forebrain Leads to Deficits of Behavioral Inhibition
}

\author{
Xuanmao Chen, ${ }^{1}$ Hong Cao, ${ }^{1,2}$ Amit Saraf, ${ }^{1}$ Larry S. Zweifel, ${ }^{1}$ and Daniel R. Storm ${ }^{1}$ \\ ${ }^{1}$ Department of Pharmacology, School of Medicine, University of Washington, Seattle, Washington 98195, ${ }^{2}$ Institute of Neurobiology, Institute of Brain \\ Science and State Key Laboratory of Medical Neurobiology, Shanghai Medical College, Fudan University, Shanghai 200032, China
}

The type 1 adenylyl cyclase (AC1) is an activity-dependent, calcium-stimulated adenylyl cyclase expressed in the nervous system that is implicated in memory formation. We examined the locomotor activity, and impulsive and social behaviors of AC1 + mice, a transgenic mouse strain overexpressing $\mathrm{AC} 1$ in the forebrain. Here we report that $\mathrm{AC} 1+$ mice exhibit hyperactive behaviors and demonstrate increased impulsivity and reduced sociability. In contrast, $\mathrm{AC} 1$ and AC8 double knock-out mice are hypoactive, and exhibit increased sociability and reduced impulsivity. Interestingly, the hyperactivity of AC1 + mice can be corrected by valproate, a mood-stabilizing drug. These data indicate that increased expression of AC1 in the forebrain leads to deficits in behavioral inhibition.

Key words: ADHD; behavioral inhibition; hyperactivity; impulsivity; sociability; type I adenylyl cyclase

\section{Introduction}

$\mathrm{AC} 1$ is a calcium/calmodulin-stimulated adenylyl cyclase that is predominantly expressed in the nervous system (Xia et al., 1991, 1993). AC1 is not stimulated by activation of Gs-coupled receptors alone but is synergistically potentiated by receptor activation paired with calcium (Wayman et al., 1994). Therefore, combinations of $\beta$-adrenergic agonists and free calcium maximally stimulate AC1 activity. AC1 is highly sensitive to intracellular free calcium and can be directly activated by $\mathrm{Ca}^{2+}$ and $\mathrm{CaM}$ in vivo (Choi et al., 1992) with half-maximal stimulation at 150-200 nM free $\mathrm{Ca}^{2+}$, concentrations just above resting free $\mathrm{Ca}^{2+}$ in neurons (Wang and Storm, 2003). Calcium-activated AC1 generates cAMP, which subsequently stimulates several downstream events required for synaptic long-term potentiation and memory consolidation (Sindreu et al., 2007).

Previous studies using $\mathrm{ACl}^{-/-}$mice have implicated $\mathrm{ACl}$ in consolidation of long-term memory (Wu et al., 1995; Wong et al., 1999; Wieczorek et al., 2012), neuropathic pain (Wei et al., 2002), and drug addiction (Krishnan et al., 2008; DiRocco et al., 2009). In contrast, $\mathrm{AC} 1+$ mice have enhanced long-term potentiation (LTP) and impaired long-term depression (LTD; Wang and Zhang, 2012; Zhang and Wang, 2013), and exhibit increased recognition memory and superior remote contextual memory (Wang et al., 2004; Shan et al., 2008). Calcium-stimulated cyclase

\footnotetext{
Received June 17, 2014; revised Nov. 3, 2014; accepted Nov. 11, 2014

Author contributions: X.C. and D.R.S. designed research; X.C., H.C., and A.S. performed research; L.S.Z. and D.R.S. contributed unpublished reagents/analytic tools; X.C., H.C., A.S., and D.R.S. analyzed data; X.C. and D.R.S. wrote the paper.

This study was supported by NIH Grants DC004156 and MH073601 to D.R.S., and MH098177 to L.S.Z. H.C. is supported by the International Postdoctoral Exchange Fellowship Program 2013 of China (201355)

The authors declare no competing financial interests.

Correspondence should be addressed to either Dr Xuanmao Chen or Dr Daniel R. Storm, Department of Pharmacology, Mail Box 357750, Health Sciences Building, University of Washington, Seattle, Washington 98195-7750. E-mail: chenx8@uw.edu or dstorm@uw.edu.

DOI:10.1523/JNEUROSCI.2478-14.2015

Copyright $\odot 2015$ the authors $\quad 0270-6474 / 15 / 350339-13 \$ 15.00 / 0$
}

adenylyl activity in hippocampal membrane preparations from $\mathrm{AC} 1+$ mice is $\sim 2.5$-fold higher than wild-type mice. In addition, PKA, MAP kinase, and CREB activities are also markedly elevated in AC1+ mice (Wang et al., 2004). Because AC1 couples intracellular free calcium to cAMP increases, AC1 is essential for several forms of synaptic plasticity (Choi et al., 1992; Villacres et al., 1998; Wang et al., 2011). For example, AC1 + mice exhibit enhanced LTP at the CA1-CA3 synapse in the hippocampus (Wang et al., 2004).

$\mathrm{AC} 1$ generates cAMP in response to calcium influx through either NMDA receptors or voltage-gated calcium channels (Wang and Storm, 2003). Interestingly, dysfunction in NMDA receptors and voltage-gated calcium channels lead to a variety of psychiatric diseases (Cross-Disorder Group of the Psychiatric Genomics Consortium, 2013; Fromer et al., 2014). In addition, animal studies and a human genome-wide association study have implicated AC1 (Krishnan et al., 2008) and AC8 (Schaefer et al., 2000; Wolf et al., 2014) in mental disorders. Because calciumcAMP signaling regulates neuronal activity, as well as mental states (Arnsten and Jin, 2012; Wolf et al., 2014), and AC1 is essential for potentiation of synaptic transmission upon vigorous electrical stimulation, we reasoned that increased expression of AC1 may cause deficits in behavioral inhibition. Here we report that $\mathrm{ACl}+$ mice are hyperactive both in their home cage and in an open field. Moreover, AC1 + mice display reduced sociability as well as increased impulsivity. In contrast, AC1/8 doubleknock-out mice are hypoactive, more social, and less impulsive. Together, these data indicate that increased expression of AC1 leads to hyperactivity and impaired behavioral inhibition.

\section{Materials and Methods}

Mice. Transgenic AC1 + mice overexpress $A c d y 1$ in the forebrain under $\alpha$-CaMKII promoter. $\mathrm{AC} 1+$ mice and $\mathrm{AC} 1 \mathrm{WT}$ littermates were bred from $\mathrm{AC} 1+$ heterozygotes and with AC1 WT mice, as previously reported (Wang et al., 2004; Shan et al., 2008). AC1 and AC8 doubleknock-out (DKO) mice were generated and bred as previously described 
A

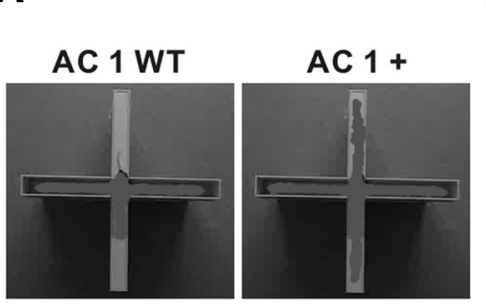

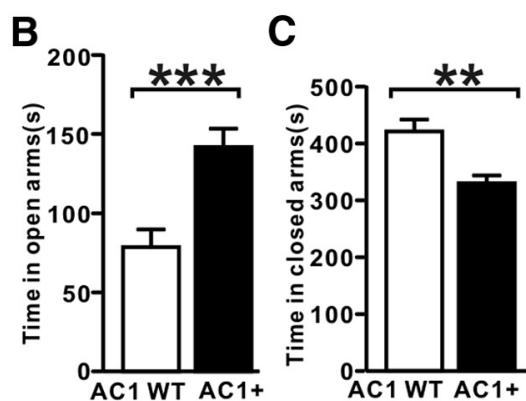

D Light-Dark Choice

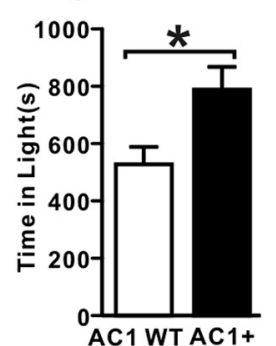

E

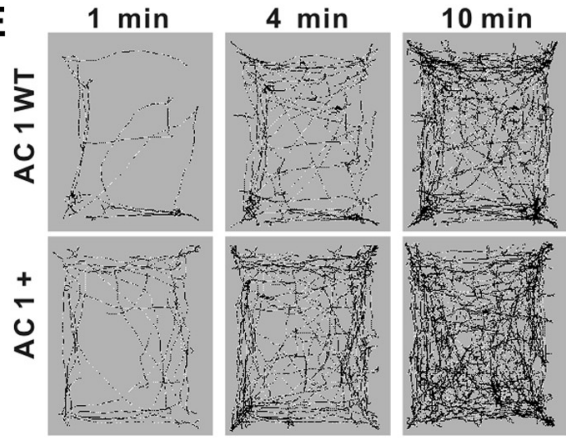

$F$

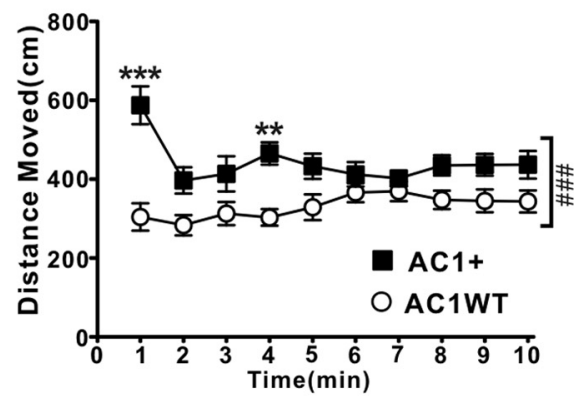

G

H
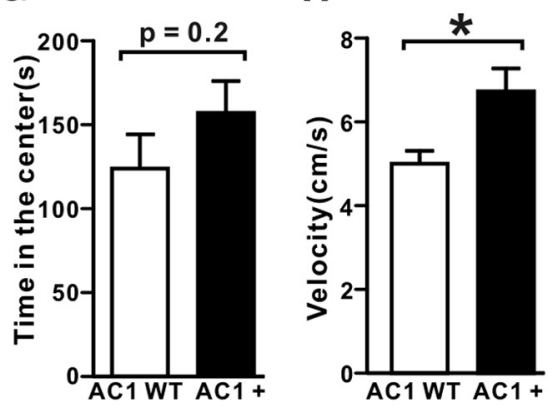

I

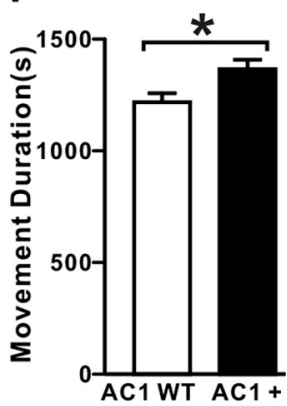

J

$\mathbf{K}$ Tail Suspension Test
L Forced Swim Test

\section{M}

NSF
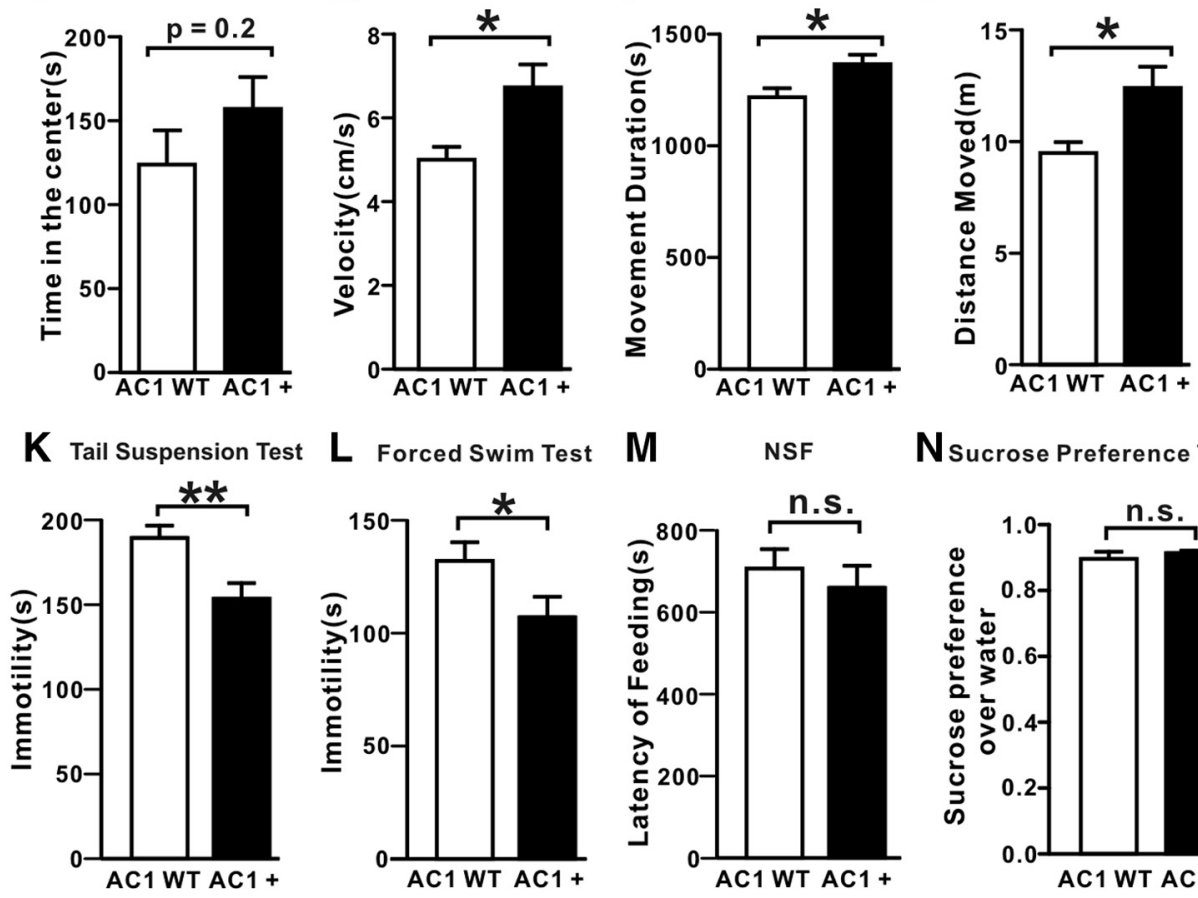

Nsucrose Preference Test

0

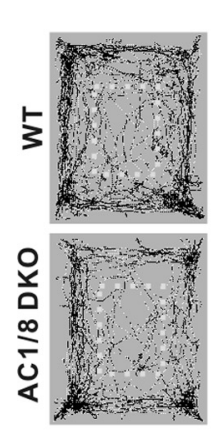

P

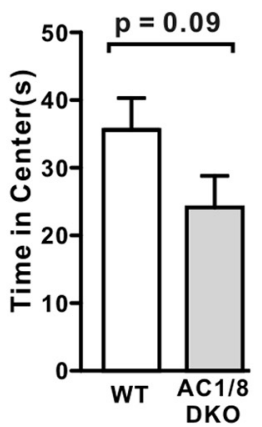

Q

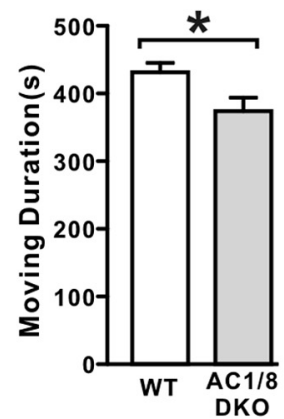

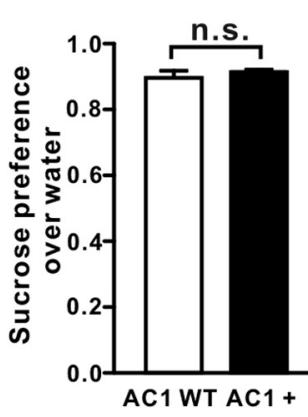

R

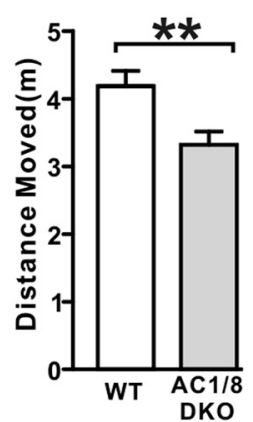


(Wong et al., 1999; Wei et al., 2002; Krishnan et al., 2008). Both strains of mice have C57BL/6 genetic background. The mice used in behavioral analysis were age-matched 2- to 4-month-old transgenic males and WT controls. Mice were maintained on a $12 \mathrm{~h} \mathrm{light} /$ dark cycle at $22^{\circ} \mathrm{C}$ and had access to food and water ad libitum. All animal procedures were approved by the Institutional Animal Care and Use Committee at the University of Washington and performed in accordance with their guidelines. Before behavioral tests, mice were handled by the investigator for $5 \mathrm{~d}$ to allow them to adjust to the investigator before starting the experiments.

Elevated plus maze test. The plus maze consisted of a plus-shaped apparatus with two open and two enclosed arms, each with an open roof, elevated $40 \mathrm{~cm}$ from the floor. Each mouse was put into center of the plus maze and its free movement was video recorded for $10 \mathrm{~min}$. The Noldus Ethovision 3.0 tracking software was used to analyze the mouse's preference for the open arms or closed arms.

Open-field test. The open-field test was conducted in an open plastic container $(38 \times 56 \times 23 \mathrm{~cm})$. At the start of each trial, the mouse was placed in a corner of the container and its movement was video recorded for $30 \mathrm{~min}$. The Noldus EthoVision 3.0 tracking software was used to analyze exploratory tracks, velocity and movement duration, and movement in the center zones.

Light/dark choice. The test apparatus $(40 \times 22 \times 18 \mathrm{~cm})$ was divided into a dark compartment and an illuminated bright compartment. Each mouse was allowed to freely move between the two compartments through an opening. The trial began when the mouse was placed at the entryway to the dark compartment; the trial duration was $30 \mathrm{~min}$ and video recorded. The total time that the animal spent in the light compartment was monitored.

Tail suspension test. Mice were suspended upside-down from their tail for $6 \mathrm{~min}$. The session was recorded by a video camera and the total time immobile was scored.

Forced swim test. Experiments were performed in a glass cylinder (14 $\mathrm{cm}$ inner diameter, with water level $13 \mathrm{~cm}$ deep) filled with room temperature water $\left(22-23^{\circ} \mathrm{C}\right)$. The legs of the mice were unable to touch the bottom of the cylinder. Mice were gently placed into the water and swimming behaviors were video recorded for $6 \mathrm{~min}$. The total duration of immobility was scored during the last $4 \mathrm{~min}$. Immobility was defined as no movement of the front or back legs and no attempt to escape.

Novelty-suppressed feeding. Exposure to a novel environment suppresses feeding behavior in rodents. Mice were food-deprived for $24 \mathrm{~h}$ before testing. A novel open container was used to present novel environments to mice. A piece of Whatman paper was placed in the center of the container with rodent chow placed on the paper. The trial duration was $15 \mathrm{~min}$ and video recorded. The latency to feeding (defined as nib-

\section{$\leftarrow$}

Figure 1. $\mathrm{AC} 1+$ mice are less anxious and hyperactive. $\boldsymbol{A}-\boldsymbol{C}$, Elevated plus maze test. $\boldsymbol{A}$, Representative track of exploration in elevated plus maze of $\mathrm{AC} 1 \mathrm{WT}$ and $\mathrm{AC} 1+$ mice. $\mathrm{AC} 1+$ mice spent more time in the open arm $(\boldsymbol{B})$ and less time in the closed arms $(\boldsymbol{C})$ than the AC1 WT mice; $n=10$ pairs of AC1 + and WT mice; ${ }^{* *} p<0.01 ; * * * 0.001 . D$, Light/dark choice test. $\mathrm{AC} 1+$ mice spent more time in the light compartment than AC1 WT mice; $n=11$ pairs. $\boldsymbol{E}-\boldsymbol{J}$, Open-field test. $\boldsymbol{E}$, Representative tracks of exploration in the open field after 1, 4, and $10 \mathrm{~min}$. $\boldsymbol{F}$, Time course of distance moved in the open field for $10 \mathrm{~min}$. Genotype effect, two-way ANOVA test; $F_{(1,240)}=65.94, \# \# p<0.0001$, *indicates significant Bonferroni post hoc difference $\left({ }^{* *} p<0.01,{ }^{* * *} p<0.001\right) . G, A C 1$ mice spent somewhat more time in the center of open field than WT mice. $\boldsymbol{H}$, The velocity of AC1 + mice was significant higher than WT mice during a 30 min test in open field. $I$, The moving duration of AC1 + mice were greater than WT mice during a 30 min test in open field. $J$, The total distance covered in 30 min was greater in AC1 + than WT mice; $n=8$ pairs; ${ }^{*} p<0.05 ;{ }^{* *} p<0.01 ;$ n.s. not significant. $\boldsymbol{K}$, Tail suspension test. The time that $\mathrm{AC} 1+$ mice were immobile was significantly shorter than AC1 WT littermates. $L$, Forced swim test. AC1 + mice were immobile for shorter periods of time than AC1 WT mice during the forced swim test. $\boldsymbol{M}$, Novelty-suppressed feeding test. The latency to feed in a novel environment was comparable between AC1 WT mice and AC1 + mice. $N$, Sucrose-preference test. AC1 WT and $\mathrm{AC} 1+$ mice had similar preference to sucrose water. For tests from $\boldsymbol{K}-\boldsymbol{N}: n=9-17$; ${ }^{*} p<0.05 ;{ }^{* *} p<0.01 ; n$.s., not significant. $\mathbf{O}-\boldsymbol{R}, \mathrm{AC1} / 8$ DKO mice were less active in the open-field test than WT mice. $\boldsymbol{O}$, Representative exploratory tracks in the open field. $\boldsymbol{P}$, Time in the center: DKO mice had reduced moving duration $(\boldsymbol{Q})$ and distance moved $(\boldsymbol{R}) ; n=11$ pairs. bling the food pellet for $4 \mathrm{~s}$ ) and the total feeding time during testing period were recorded.

Sucrose preference test. Mice were housed individually for this test. To reduce the possible stressful response to novelty, $24 \mathrm{~h}$ before actual testing mice were able to choose freely between two glass tubes with small sipping tip (one with $2 \%$ sucrose solution and another one with regular water). During next $4 \mathrm{~d}$, two leak-proof liquid tubes (one with water and another with $2 \%$ sucrose) were presented. To prevent possible effects of side preference in drinking behavior, positions of the tubes were switched at $24 \mathrm{~h}$ intervals. The consumption of water and sucrose solution was estimated by weighing the bottles. Preference for sucrose solution was calculated as the percentage of sucrose solution ingested relative to the total amount of liquid consumed.

Actogram monitoring in the home cage. Mice were individually housed and a photobeam sensor was installed at the top of each cage. Mice were maintained on a $12 \mathrm{~h}$ light/dark cycle at $22^{\circ} \mathrm{C}$ and had access to food and water ad libitum. Activity counts were collected every $5 \mathrm{~min}$. Actograms (reflecting activity) were acquired for $5 \mathrm{~d}$ with a Vitalview data system and analyzed with Actiview 1.2 (Mini Mitter Company).

Object exploration in an open field. Open plastic containers $(38 \times 56 \times$ $23 \mathrm{~cm}$ ) were used and mice were first habituated in the arena for $3 \mathrm{~min}$. A novel object was then placed in the center and mice were allowed to explore for $5 \mathrm{~min}$. The Noldus EthoVision 3.0 tracking software was used to analyze exploratory tracks.

Cliff avoidance reaction test. Cliff avoidance reaction (CAR) test (Fromer et al., 2014) was assessed using a round wooden platform (diameter, $20 \mathrm{~cm}$ ), supported by a wooden rod (height, $50 \mathrm{~cm}$; Matsuoka et al., 2005; Yamashita et al., 2013). The test was initiated by placing an animal on a platform. The latency from an initial placement on the platform until falling was monitored. Mice that fell from platforms were immediately and gently placed back on the platforms, and the test continued until 60 min had elapsed. Mice that did not fall from platforms were tested for the same duration of time and the latency was counted as $60 \mathrm{~min}$.

Rotarod test. Mice were placed on a stationary cylinder (Rotarod; San Diego Instruments) with the head of the mouse against the direction of rotation. After $5 \mathrm{~s}$, the rotarod was switched on from a starting speed of 4 $\mathrm{rpm}$, accelerating to a maximal rotation speed of $30 \mathrm{rpm}$ during a $5 \mathrm{~min}$ period. The mice were timed until they fell. Mice were tested successively in four trials during $1 \mathrm{~d}$, with 30 min intervals between trials. In each case, a total of 16 trials were run over $4 \mathrm{~d}$. The duration for staying on rotating rod during each trial was recorded.

Object exploration in the open field. This test was conducted in an open container $(38 \times 56 \times 23 \mathrm{~cm})$. The procedure was as described previously with minor modifications (Brechbühl et al., 2013). Briefly, before the experiment was initiated, mice were habituated to the arena for $3 \mathrm{~min}$. Two Eppendorf tubes either containing $1 \mathrm{ml}$ fox odor trimethylthiazoline (TMT; $8 \mu \mathrm{M}$ ) or $1 \mathrm{ml}$ vehicle held by identical containers were put in opposite corners of the open field. There were several holes in the top of the Eppendorf tubes to allow TMT or vehicle to evaporate and to be smelled by mice. Mice were allowed to explore the open field containing the two Eppendorf tubes with or without TMT for $5 \mathrm{~min}$. The movement of the mice was videotaped. The recorded video file was analyzed by off-line video tracking software (EthoVision software). Distance traveled, moving duration, time spent in the corner proximal to each tube was measured. Risk-assessment behavior in response to TMT was scored.

Startle response and prepulse inhibition. Startle response and prepulse inhibition were tested in sound-attenuating startle chambers (SR-Lab, San Diego Instruments). The procedure was as described previously (Soden et al., 2013). Briefly, baseline startle response was measured following a $5 \mathrm{~min}$ habituation period with a series of seven trials of $40 \mathrm{~ms}$ white noise pulses escalating from 80 to $120 \mathrm{~dB}$, with an ITI of $30 \mathrm{~s}$. This series was repeated 10 times for a total of 70 trials. To measure prepulse inhibition $\mathrm{ACl}+$ mice and controls were given a $10 \mathrm{~min}$ habituation period followed by five trials of $120 \mathrm{~dB}$ startle pulse-alone, followed by 50 trials which pseudorandomly alternated between $120 \mathrm{~dB}$ pulse-alone, one of three prepulse intensities (70,75, or $80 \mathrm{~dB}$ ), or null (no startle), 20 with a variable ITI of 5-25 s. Prepulse trials consisted of a $20 \mathrm{~ms}$ duration prepulse at the indicated intensity occurring $100 \mathrm{~ms}$ before the $40 \mathrm{~ms} 120$ $\mathrm{dB}$ startle pulse. 
A

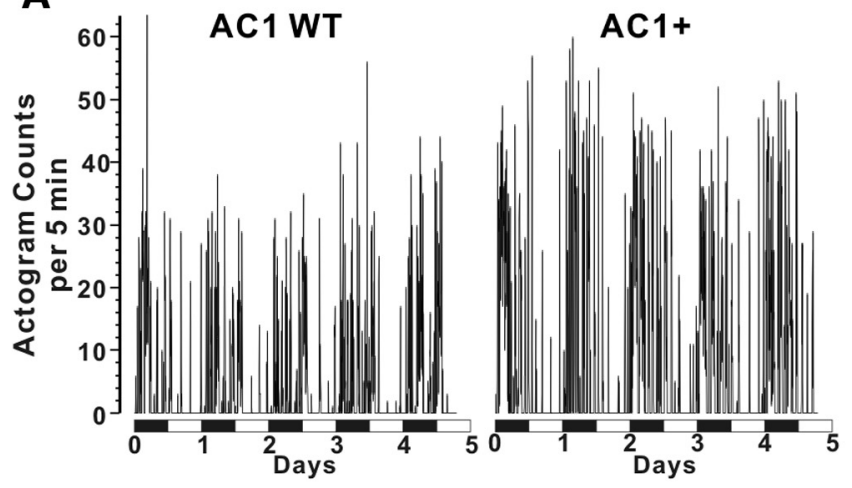

D

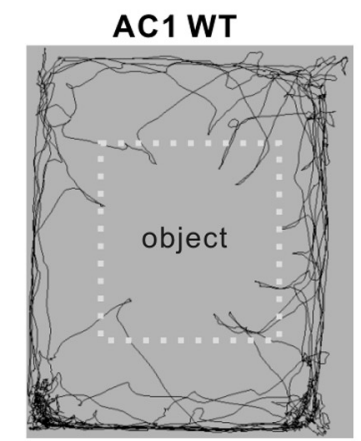

G

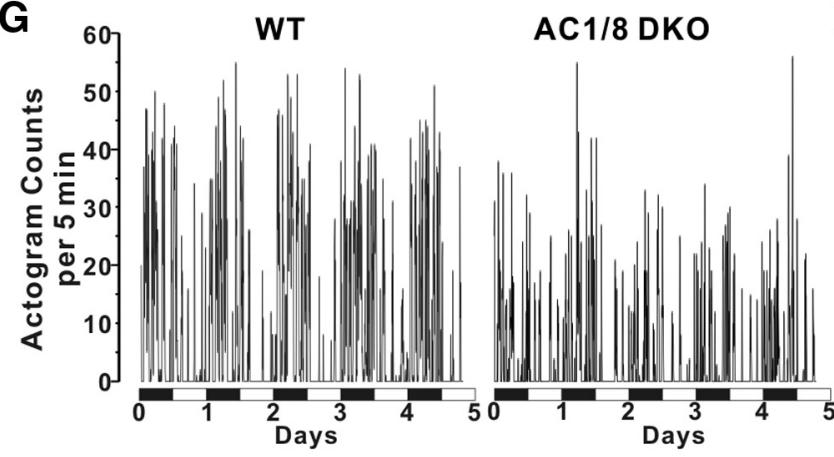

J

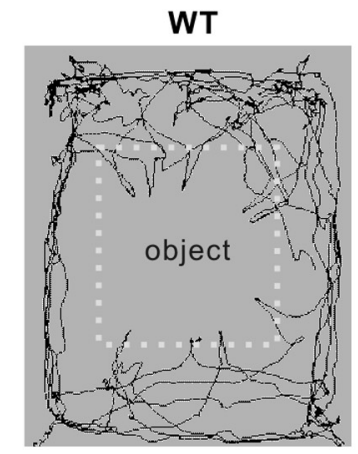

\section{J}

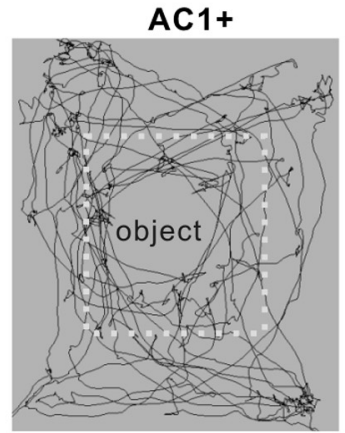

B

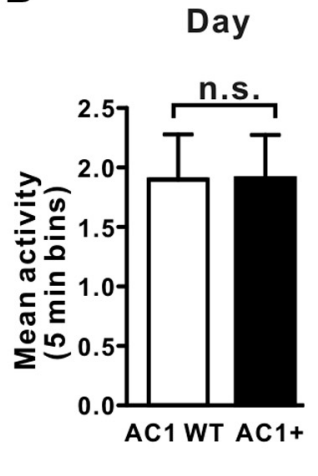

E

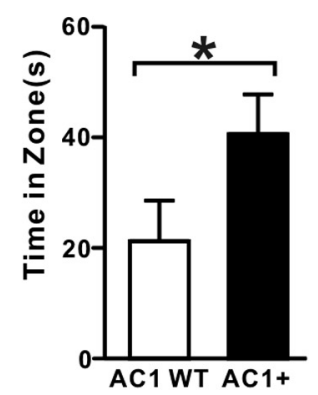

H

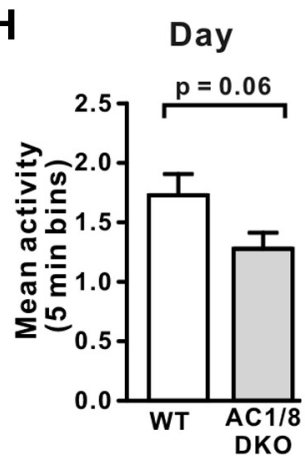

K
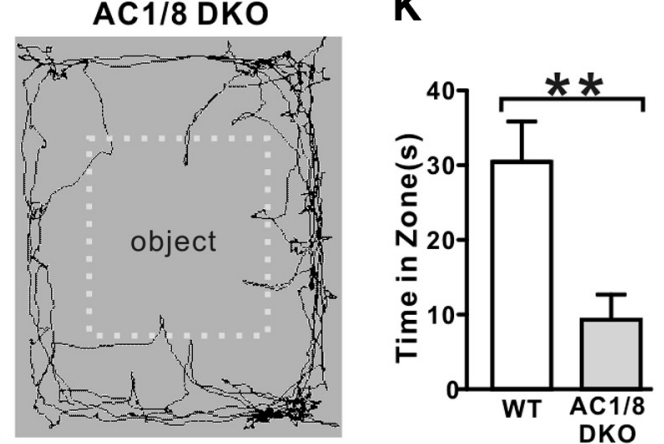

C

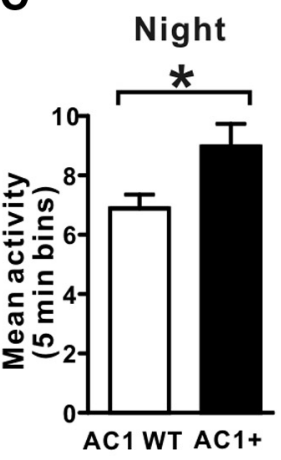

F

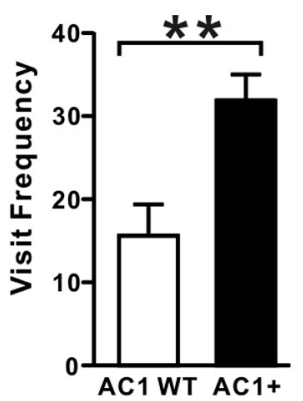

I

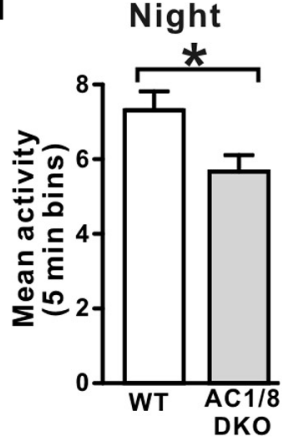

L

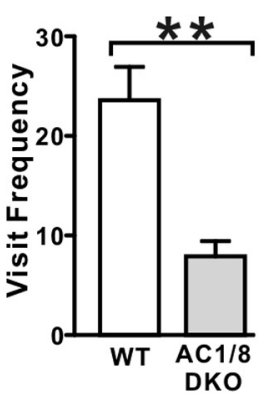

Figure 2. $\mathrm{AC} 1+$ mice are hyperactive in home cage and more actively explored a novel object in an open field. $A-C, A C 1+$ mice had increased activity in their home cages. $A$, Representative actogram from AC1 WT and AC1 + mice continuously recorded for over 5 d. Activity counts were collected in 5 min bin. Average locomotor activity of AC1WT and AC1+ mice in the daytime $(\boldsymbol{B})$ and nighttime $(\boldsymbol{C})$. AC1 + mice were more active than in AC1WT mice in the nighttime, but not in the daytime; ${ }^{*} p<0.05 ; n=11$ pairs. $\boldsymbol{D}-\boldsymbol{F}$, AC1+ mice were more active in examining a novel object in the open field. Mice were habituated to the open field for 3 min before introducing a novel object. $\boldsymbol{D}$, Representative exploration track of mice in the open field with a novel object in the center. $\boldsymbol{E}, \mathrm{AC} 1+$ mice spent more time in the object zone. $\boldsymbol{F}$, The frequency of visiting the novel object zone was higher in $\mathrm{AC} 1+$ mice; $n=$ 11 pairs; ${ }^{*} p<0.05,{ }^{* *} p<0.01$. Similar results were obtained with a second novel objects. $\mathbf{G}-\mathbf{I}, \mathrm{AC1} / 8$ DKO mice were less active in their home cages. $\mathbf{G}$, Representative actogram. Average locomotor activity of DKO mice and WT mice in the daytime $(\boldsymbol{H})$ and nighttime $(\boldsymbol{I}) ; \boldsymbol{n}=11$ pairs. $\boldsymbol{J}-\boldsymbol{L}, \mathrm{AC1} / 8 \mathrm{DKO}$ mice spent less time examining a novel object in the open field than WT. J, Representative exploration track of mice in the open field with a novel object in the center. DKO mice spent less time in the object zone $(\boldsymbol{K})$ and examined the object less frequently than WT $(L) ; n=10$ pairs. 
A
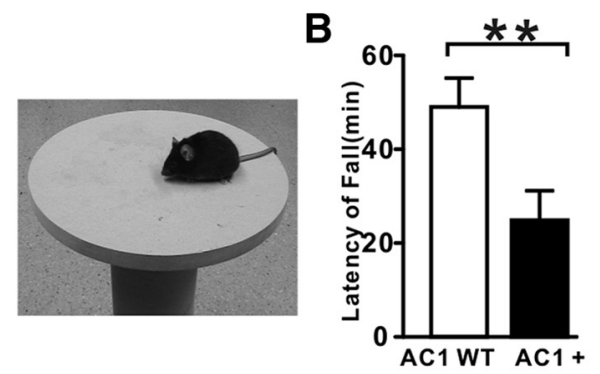

D

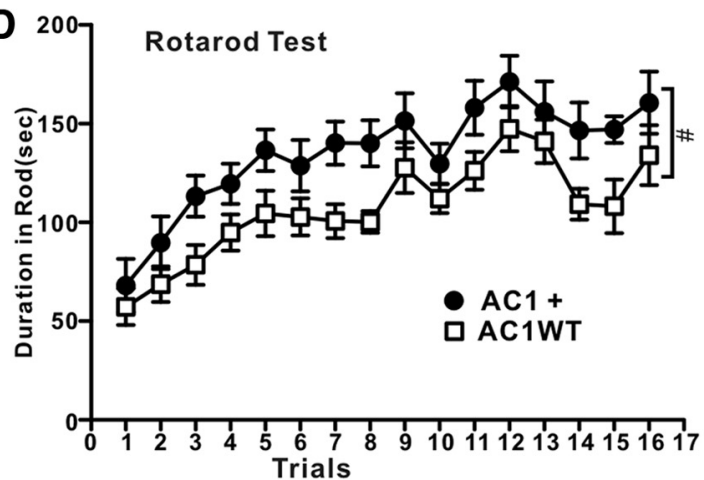

AC1 WT

F

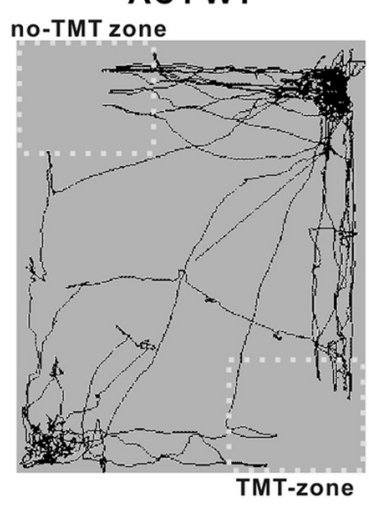

G

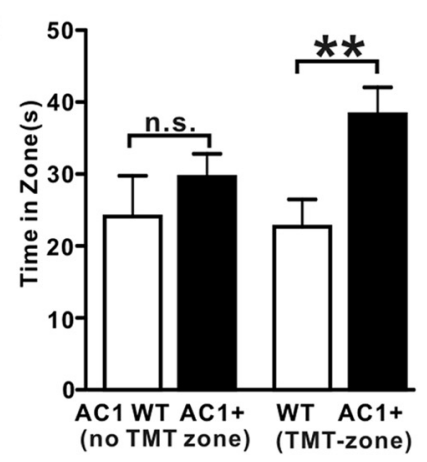

K
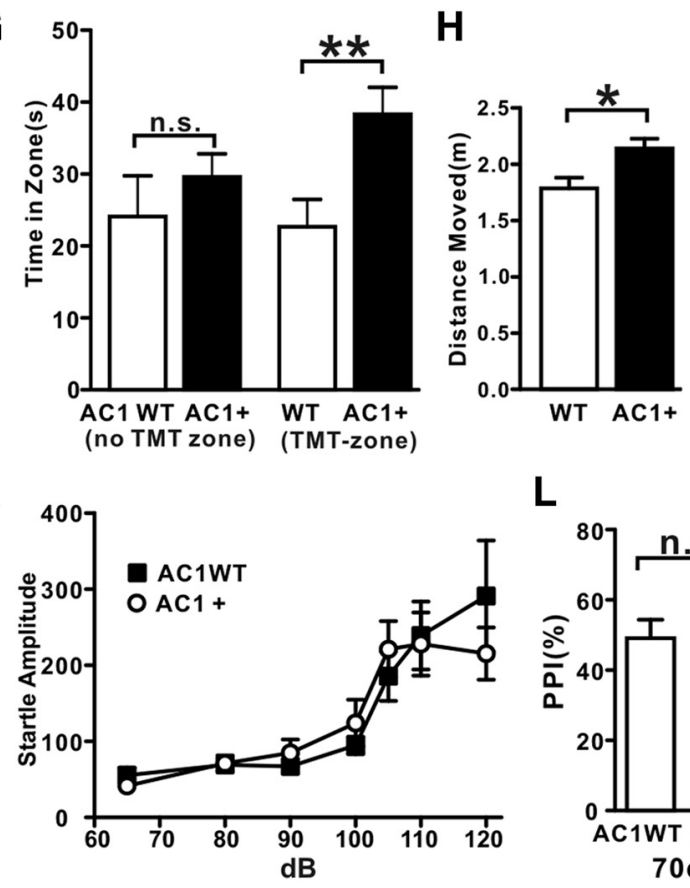

L no-TMT zone

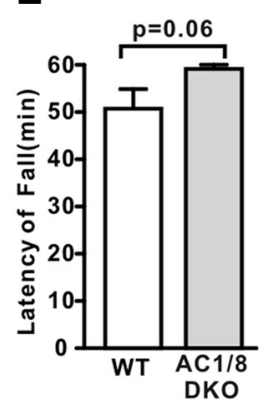

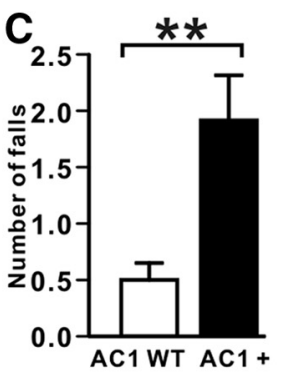

E

TMT-zone

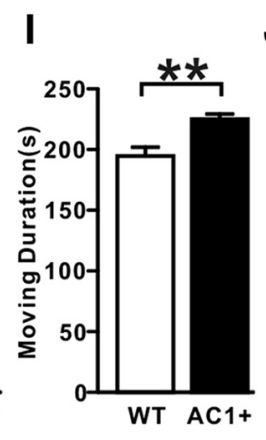

J
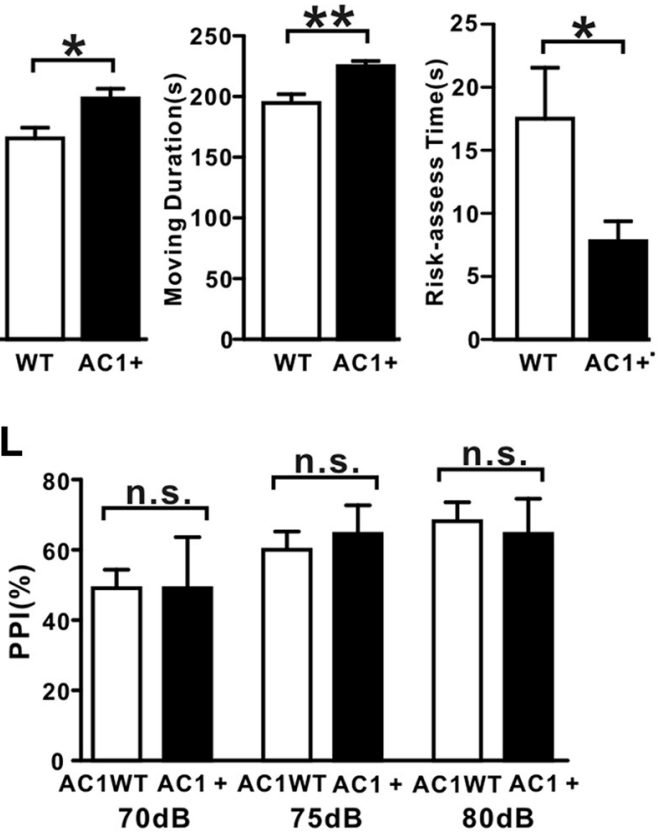
Sociability test. The apparatus for sociability test was a rectangular, three-chamber box. Each chamber was $22 \times 20 \times 13 \mathrm{~cm}$ and the walls of chamber were made from Plexiglas. The subject mouse was allowed to freely explore each chamber. These two identical wire mesh cups were placed inside the apparatus, one in left and one in right. We used a young (6-week-old) male C57BL6 mouse that had no prior contact with the subject mouse as the interacting target mouse. After the subject mouse has habituated in the apparatus for $5 \mathrm{~min}$, one C57BL/ 6 target mouse was then placed inside a wire cup in a chamber in one side. The other wire cup was empty in the other side. The subject mouse then freely explored any of the three chambers. The exploration/interaction lasted $10 \mathrm{~min}$ and was video recorded. The exploration time in each chamber was analyzed by EthoVision software.

Social choice test. The social interaction in open-field test was performed as described previously with modifications (Tabuchi et al., 2007). The test was performed in the open-field arena $(40 \times 70 \times 25 \mathrm{~cm})$. A young stranger naive C57BL/ 6 mouse (6-week-old male) caged in a cylinder wire mesh cage $(6 \times 6 \times 10 \mathrm{~cm})$ that was used as a social cue. A caged object and a caged stranger mouse were placed simultaneously in the opposite sides of the arena. The test mouse was then allowed to explore either the object or the caged stranger mouse. The movement of the mouse was videotaped. The recorded video file was analyzed by offline video tracking software (EthoVision software). Time spent in the corner proximal to the stranger cage was measured.

Reciprocal interaction test. Subject mouse and an age-matched target mouse were introduced into a neutral cage with fresh bedding. The cage was used only once. The mice had never interacted previously. Social interactions between mice were videotaped for $10 \mathrm{~min}$. Time spent in aggressive interactions, such as attacking, wrestling, biting the dorsal surface, and time spent in nonaggressive interactions, including noseto-nose sniffing, anogenital sniffing, and grooming were monitored manually.

Resident/intruder aggression test. Male-male aggression test was observed by the resident/intruder assay (Wang et al., 2006). Adult, sexually naive mice were housed individually for $10 \mathrm{~d}$, and their bedding was not changed for $4 \mathrm{~d}$ before testing. The latency of attack of the host male was observed during a $15 \mathrm{~min}$ period by introducing a group-housed, sexually inexperienced, unfamiliar, C57BL/6J adult (8-10 weeks old) male into their home cage. Attack by the resident male was defined as aggressive biting and chasing.

Olfactory habituation/dishabituation test. All the tests were done in home cages, where the test mouse was singly housed. Odor stimulations were delivered with a cotton-tipped swab placed through the cage top $\sim 8$ $\mathrm{cm}$ above the bedding. After $10 \mathrm{~min}$ of habituation with a cotton-tipped swab without odor stimulant, the test mouse was stimulated by several application of odorants: water, citralva $(10 \mu \mathrm{M}), \mathrm{C} 57 \mathrm{BL} / 6 \mathrm{~J}$ male mouse urine (1:30 dilution), and eugenol $(10 \mu \mathrm{M})$. Each stimulus was $2 \mathrm{~min}$ in duration with $1 \mathrm{~min}$ intertrial interval. The sequence of the odor stimulation was as follows: water1, water2, water3, citralva1, citralva2, citralva3, urine1, urine2, urine3, eugenol1, eugenol2, and eugenol3. Time spent sniffing the odorants was measured by manual observation with a stopwatch. Sniffing was only scored when the test mouse's nose was close

\footnotetext{
Figure 3. $A C 1+$ mice exhibit increased impulsivity. $A-C$, CAR test. $A, A$ platform used in the CAR test. $\boldsymbol{B}$, The latency for the first fall from the platform was shorter for $\mathrm{AC} 1+$ mice than WT mice. $C$, The total number of falls during a 60 min test was greater in $A C 1+$ mice; $n=12$ pairs; ${ }^{* *} p<0.01 . D, A C 1+$ mice stayed longer on the Rotorod than AC1 WT mice in the accelerating Rotated test; $n=11$ pairs; genotype effect, two-way ANOVA test; $F_{(1,300)}=7.99$, \#p $<0.05$. $E, A C 1 / 8$ DKO mice had slightly increased latency of fall than WT mice in the CAR test; $n=12$ WT; $n=14$ AC1/8 DK0 mice. $\boldsymbol{F}-J, A C 1+$ mice did not avoid a predatory fox odor, TMT, as much as WT mice. $\boldsymbol{F}$, Representative exploratory tracts in the open field when TMT was in the lower right-hand corner. $\mathbf{G}, \mathrm{AC1}+$ mice spent more time in the TMT zone than WT mice. The distance moved $(\boldsymbol{H})$ and moving duration $(\boldsymbol{I})$ was higher with $\mathrm{AC} 1+$ mice than WT mice. $\boldsymbol{J}$, The riskassessing time was shorter in $\mathrm{AC} 1+$ mice than WT mice; $n=10$ pairs; ${ }^{*} p<0.05 ;{ }^{* *} p<0.01$. $\boldsymbol{K}, \boldsymbol{L}$, Acoustic startle response and prepulse inhibition test. AC1 have a normal startle response $(K)$, two-way ANOVA test; $F_{(1,96)}=0.01, p=0.94$. Prepulse inhibition was normal in $\mathrm{AC} 1+$ mice $(L) ; n=9$ pairs, n.S., not significant.
}

from and pointing to the swab. Biting of the swab by the mouse was excluded.

Kainate administration and seizure-like activity evaluation. Kainate (10 $\mathrm{mg} / \mathrm{kg}$ body weight, a subepileptic dose) or saline was administrated by intraperitoneal injection. We used the Racine-seizure scale (Racine, 1972 ) to evaluate seizure-like behaviors: no response (0), staring and reduced locomotion (1), activation of extensors and rigidity (2), repetitive head and limb movements (3), sustained rearing with clonus (4), loss of posture (5), and status epilepticus and death (6).

Fiber fluorescence confocal endomicroscopy calcium imaging. We used fiber fluorescence confocal endomicroscopy (FFE), an advanced in vivo calcium imaging system (Cellvizio Neuropak deep brain imaging system, Mauna Kea Technologies) in combination with viral-mediated gene delivery to hippocampal CA1 region to monitor overall CA1 neuronal activation in response to stimulation (Vincent et al., 2006; Soden et al., 2013). We stereotaxically injected $1 \mu$ l GCaMP6 (a calcium-sensitive fluorescence indicator)-expressing AAV1 (Vector Core, University of Pennsylvania) into CA1 region (coordination, AP: -1.7 to $-1.9 \mathrm{~mm}$; ML: $-1.5 \mathrm{~mm}$; DV -1.3 to $-1.5 \mathrm{~mm}$ ). Then a cannula was installed on the top of head. Imaging was performed 3 weeks after surgery and GCaMP6 expression. Mice were first positioned on a stereotaxic apparatus under isoflurane anesthesia. A CerboFLEX Neuropak endomicroscope fiber-optic probe was hooked to a vertical micropipette guide of the stereotaxic apparatus that allows positioning of the imaging probe and moving through cannula until image was seen. After imaging probe reached GCaMP6 expression site in CA1 region, it was tightly fixed to cannula by a screw. Mice were then put in a box with food and water $a d$ libitum for recovery from anesthesia for $>1 \mathrm{~h}$. After waking, mice could freely behave with the imaging probe (the endomicroscope) on the top of its head. Mice were then placed in a foot shock box and after 2 min exploration; 2 s $0.7 \mathrm{~mA}$ foot shock stimulation was delivered. Neuronal activity was monitored with or without foot shock by the imaging probe. Imaging data were acquired at $11.7 \mathrm{~Hz}$ by Cellvizio 488 (Mauna Kea Technologies) and analyzed with IC Viewer 3.8 (Mauna Kea Technologies) off-line in combined with Graphpad Prism 5. After imaging, mice were killed and brain tissues were fixed with 4\% PFA and then subjected to immunological staining using primary antibodies against GFP (Cata$\log$ \#A-11120, Invitrogen) verify the imaging location.

Membrane preparations and Western analysis. Adult mice were killed by cervical dislocation, their hippocampi were quickly dissected on ice, flash frozen in liquid nitrogen, and stored at $-70^{\circ} \mathrm{C}$ until use. Frozen hippocampal tissue was pulverized and homogenized in 10 volumes of homogenization buffer (10 mM Tris, $\mathrm{pH} 7.4,320 \mathrm{~mm}$ sucrose, $1 \mathrm{~mm}$ EDTA, 1 mм EGTA, $100 \mathrm{~mm} \mathrm{NaF}, 1 \mathrm{~mm} \mathrm{Na}_{3} \mathrm{VO}_{4}, 1 \mathrm{~mm}$ PMSF, a protease inhibitor tablet; Roche) and 1:100 dilutions of Sigma-Aldrich phosphatase 2 and phosphatase 3 inhibitor). Homogenates were cleared by centrifugation $(10 \mathrm{~min}$ at $1000 \times \mathrm{g})$, supernatants again centrifuged at $10,000 \times g$ for 50 min to obtain crude plasma membrane from pellets. Crude plasma membrane pellets were solubilized in homogenization buffer containing $0.5 \%$ NP40 and centrifuged at $15,000 \times g$ for $5 \mathrm{~min}$. An equal volume of $2 \times$ SDS-PAGE sample buffer was added to the membrane fractions and finally membranes were probed by Western blot analysis (Eckel-Mahan et al., 2008). Primary antibodies used were at the following dilutions, rabbit anti-p-GluR1 (Ser845, 1:1000; Millipore), rabbit anti-pGluR1 (Ser831, 1:500; Millipore), and rabbit anti-GluR1 (1:500; Millipore Bioscience Research Reagents). Phosphorylated-protein blots were stripped in $25 \mathrm{~mm}$ glycine, $\mathrm{pH} \mathrm{2}$, and 1\% SDS (stripping buffer) for $30 \mathrm{~min}$, and reprobed for total GluR1-AMPA receptor signal.

Valproate administration. Mice received intraperitoneal injection of valproate (Tocris Bioscience, $200 \mathrm{mg} / \mathrm{kg}$ ) or saline in a volume of 10 $\mathrm{ml} / \mathrm{kg}$ (Chiu et al., 2013; Han et al., 2013). Valproate was injected three times before each behavioral assay (12:00 and 18:00 on the day before the assay and 10:00-15:00 of the day of test), and behavioral tests were performed $30 \mathrm{~min}$ after final injection.

Novelty object recognition. The novel-object recognition and memory retention test was used to test recognition memory. The mice were first habituated in a cage for $30 \mathrm{~min}$ before training, after which two plastic blocks (A1 and A2) were presented during 5 min of training. Object recognition was scored by the time percentage spent in each object-conditioned 
A
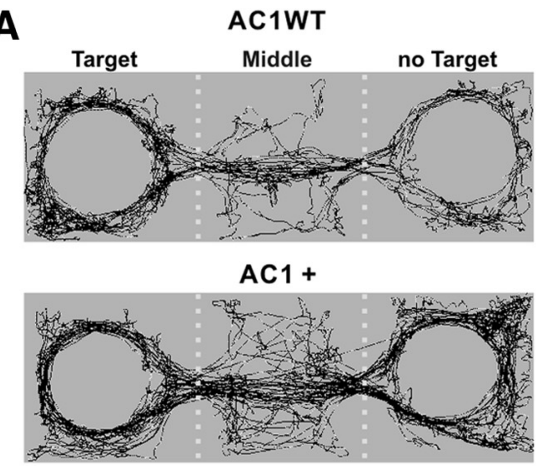

C

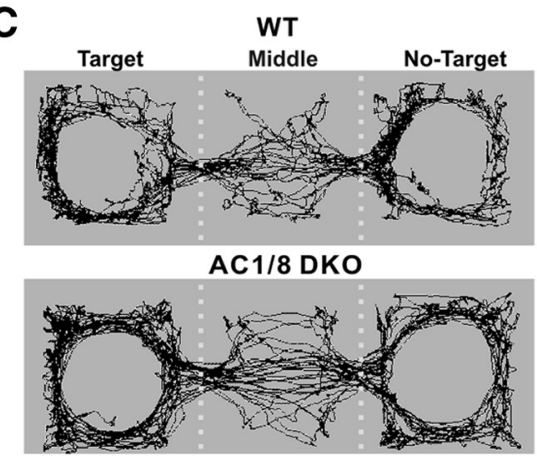

E
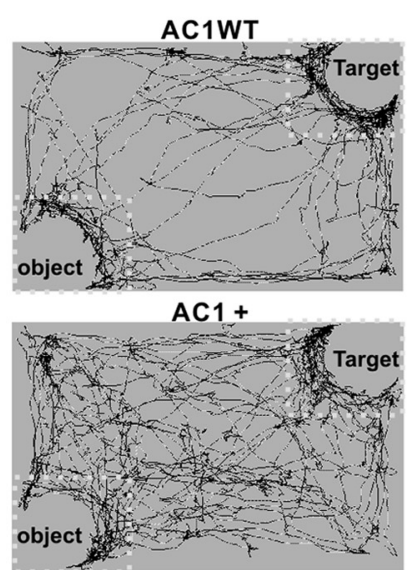

G

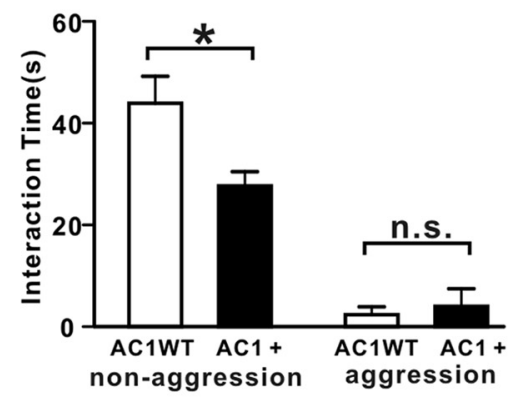

J

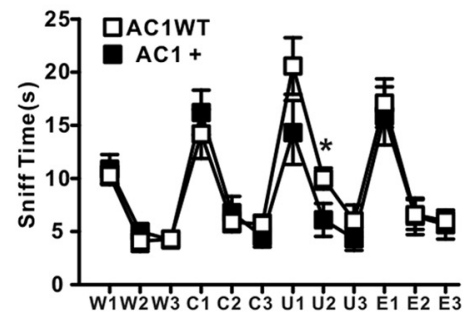

B

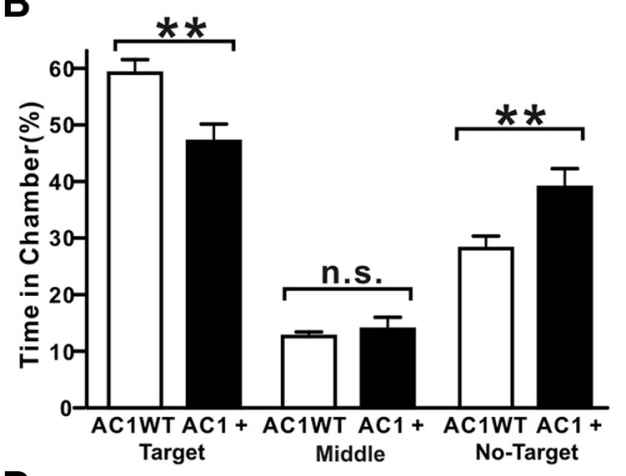

D

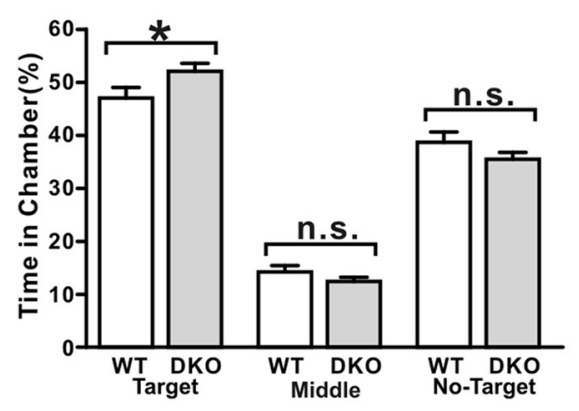

F

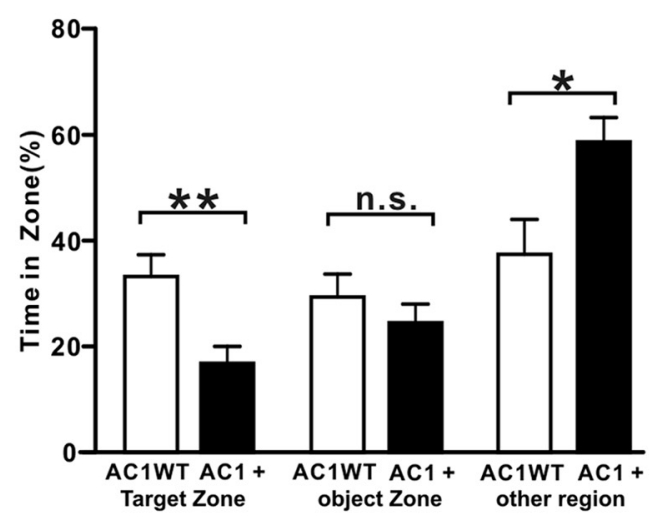

H
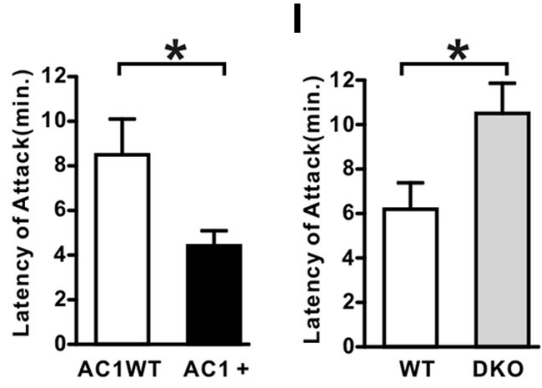
compartment. When the mice were tested for memory retention 1 and $24 \mathrm{~h}$ later, one of the original blocks was replaced by a new object (B), and the mouse was scored for recognition during $5 \mathrm{~min}$ of testing.

Amphetamine administration. Basal locomotor activity of each mouse was determined before drug administration for $30 \mathrm{~min}$. Then, mice received an intraperitioneal injection of the test drug (D-amphetamine hemisulfate, Sigma-Aldrich) that were dissolved in saline or vehicle and were placed again in the open field. At $10 \mathrm{~min}$ after the injection, recording of locomotor activity resumed and lasted for 35-40 min. The distance moved in the open field has been analyzed.

Data analysis. Data were analyzed with Excel (Microsoft), Clampfit 10.0 software (Molecular Devices), and GraphPad Prism 5. If not otherwise indicated, statistical analysis was based on unpaired Student's $t$ test with a two-tailed distribution. Not significant (n.s.), ${ }^{\star} p<0.05,{ }^{* *} p<$ 0.01 , and ${ }^{* * *} p<0.001$. Data were considered as statistically significant if $p<0.05$. Values are expressed as mean \pm SEM.

\section{Results}

AC1 + mice exhibit hyperactivity and an anxiolytic phenotype

$\mathrm{AC} 1+$ mice were first subjected to several behavioral tests for anxiety. In the elevated plus maze, $\mathrm{ACl}+$ spent more time in the open arm and less time in the closed arm than WT mice (Fig. $1 A-C)$. When they were tested for their preference for a light or dark chamber, $\mathrm{AC} 1+$ mice spent more time in the light chamber than WT controls (Fig. 1D). In the open-field test, $\mathrm{AC} 1+$ mice exhibited hyperactive exploratory behavior compare with WT mice (Fig. 1E,F). Although both mice spent comparable time in the center of the open field (Fig. $1 G$ ), the velocity of exploration (Fig. $1 H$ ), moving duration (Fig. $1 I$ ), and distance traveled (Fig. $1 J)$ of $\mathrm{AC} 1+$ mice in the open field were all significantly greater than WT littermates. These data indicate that overexpression of $\mathrm{AC} 1$ in the forebrain leads to anxiolytic and hyperactive behaviors. Moreover, we found that $\mathrm{AC} 1+$ mice also have shorter immobility in the tail suspension test and forced swim test (Fig. $1 K, L)$. However, the novelty-suppressed feeding test and sucrose preference test are normal in AC1 + mice compared with WTs (Fig. $1 M, N$ ), indicating it is not an antidepression phenotype, but rather a hyperactive phenotype. In contrast, AC1 and AC8 DKO mice were hypoactive in the open-field test (Fig. 1O-R). The moving duration and distance moved in the open field of DKO mice were significantly lower than WT controls, whereas the time in the center was slightly lower. Thus, $\mathrm{AC} 1+$ mice are hyperactive and $\mathrm{AC1} / 8 \mathrm{DKO}$ mice are hypoactive.

We also monitored locomotor activity of $\mathrm{AC} 1+$ and WT mice in their home cages. $\mathrm{AC} 1+$ mice were markedly more active than

\footnotetext{
$\leftarrow$

Figure 4. $\mathrm{AC} 1+$ mice exhibit reduced sociability. $\boldsymbol{A}, \boldsymbol{B}$, Three-chamber sociability test. $\boldsymbol{A}$, Representative exploration track. $\boldsymbol{B}, \mathrm{AC} 1+$ mice spent less time in the chamber with the mouse-target and more time in chamber without the target mouse than AC1 WT mice; $n=13$ pairs; ${ }^{* *} p<0.01$. C, D, AC1/8 DK0 mice exhibited slightly increased sociability. C, Representative exploration track in three-chamber sociability test. $D, A C 1 / 8$ DKO mice spent significantly more time in interacting with the target mouse than WT mice; $n=16$ pairs; ${ }^{*} p<0.05 ;$ n.s., not significant. $\boldsymbol{E}, \boldsymbol{F}$, Social choice test of AC1 + mice. $\boldsymbol{E}$, Representative exploration tracks in the open field. $\boldsymbol{F}, A C 1+$ mice interacted less to a social cue than WT mice in an open arena; $n=9$ pairs. $\mathbf{G}$, Reciprocal interaction test of $\mathrm{AC} 1+$ mice. $\mathrm{AC} 1+$ mice exhibited less nonaggression interaction time with target mouse than AC1 WT mice in neutral clear cages; $n=15$ pairs, ${ }^{*} p<$ 0.05 , n.s., not significant. $\boldsymbol{H}, \boldsymbol{I}$, Resident-intruder aggression assay of AC1+ mice $(\boldsymbol{H})$ and DKO mice $(\boldsymbol{I})$. AC1 + mice had shorter latency than WT mice to attack a male intruder to their home $\operatorname{cages}(\boldsymbol{H}) ; n=11$ pairs. However, AC1/8 DKO mice had higher latency to attack a male intruder $(I) ; n=10$ pairs; ${ }^{*} p<0.05$. J, Olfactory habituation/dishabituation test of AC1 + mice; $w 1$, w2, and w3: the first, second, third water $\mathrm{Q}$-tip exposure; three times of citralva (C), three times male mouse urine $(U)$, and three times eugenol (E) Q-tips were exposed subsequently. AC1+ and WT mice spent comparable time to sniff all odorant Q-tips except that AC1 + mice sniffed shorter during the second male urine exposure; $n=9 \mathrm{AC} 1+$ mice; $n=10$ WT mice.
}

WT mice during the nighttime but not during daytime (Fig. 2A$C)$. Moreover, $\mathrm{AC} 1+$ mice were more exploratory to a novel object and they spent more time examining a novel object than WT mice in the open field even when the object was in the center of the arena (Fig. $2 D-F$ ), confirming the hyperactivity of the $\mathrm{AC} 1+$ mice. In contrast, $\mathrm{DKO}$ mice were less active in their home cage (Fig. 2G-I) and they examined a novel object less often than WT mice in the open field (Fig. $2 J-L$ ). These data indicate that increasing $\mathrm{AC} 1$ expression promotes locomotor and exploratory activity.

\section{Increased impulsivity of AC1 + mice}

To test whether $\mathrm{AC} 1+$ mice were more impulsive, they were subjected to the CAR test (Fig. 3A). The latency of falling from the elevated platform was much shorter with $\mathrm{AC} 1+$ mice compared with WT mice (Fig. 3B). Moreover, during a $60 \mathrm{~min}$ test period $\mathrm{AC} 1+$ mice fell more frequently than WT mice (Fig. $3 C$ ). Fifty percent of WT mice and $92 \%$ of $\mathrm{AC} 1+$ mice fell from the platform at least once during the $60 \mathrm{~min}$ test period. $\mathrm{AC} 1+$ mice exhibited slightly better motor skills than WT mice in the Rotarod test (Fig. 3D), suggesting that the frequent falls of $\mathrm{AC} 1+$ mice during the CAR assay were not due to poor physical coordination but greater impulsivity. We also subjected the DKO mice to the CAR test. The latency for falling was slightly greater with DKO mice (Fig. 3E). These data suggest that calciumactivated adenylyl cyclases may influence behavioral impulsivity.

Mice normally freeze and assess potential risk out of innate fear when exposed to TMT, a predator fox odor (Brechbühl et al., 2013). Therefore, we examined the behavior of AC1 + mice when they were exposed to TMT in an open field. AC1 + mice explored the TMT-zone much more actively than WT mice (Fig. $3 F$ ). The distance moved and moving duration was higher in $\mathrm{AC} 1+$ mice than in WT mice when TMT was present at one corner (Fig. $3 G-I)$. Moreover, the risk-assessing time of $\mathrm{AC} 1+$ mice was much shorter than that of WT mice (Fig. 3J). Because AC1+ mice detect odorants normally, the reckless exploratory behavior of AC1 + mice in the presence of TMT is most likely due to lack of behavior inhibition.

To test whether $\mathrm{AC} 1+$ mice show deficit of sensory gating, we subjected $\mathrm{AC} 1+$ mice to the acoustic startle response and prepulse inhibition. $\mathrm{AC} 1+$ mice exhibited a normal startle response (Fig. $3 K$ ) and prepulse inhibition (Fig. $3 L$ ), comparable with WT mice, demonstrating that $\mathrm{AC} 1+$ mice have normal acoustic sensory function and do not exhibit an alteration of sensory gating. Collectively, these data indicate that $\mathrm{AC} 1+$ mice demonstrate increased hyperactivity and impulsivity without developing extreme manic phenotype.

\section{AC1 + mice show reduced sociability}

$\mathrm{AC} 1+$ mice were monitored for sociability. In the three-chamber sociability test, $\mathrm{AC} 1+$ mice spent less time interacting with the target mouse compared with WT mice (Fig. 4A,B), suggesting $\mathrm{AC} 1+$ mice have reduced sociability. In contrast, $\mathrm{AC} 1 / 8 \mathrm{DKO}$ mice spent more time in the target chamber than WT mice (Fig. $4 C, D)$. Moreover, in the social choice test, $\mathrm{AC} 1+$ mice interacted to a less extent with the mouse target and spent more time exploring other regions in the field compared with WT mice (Fig. $4 E, F)$. In the reciprocal interaction test in a clear new cage, $\mathrm{AC} 1+$ mice did not exhibit more aggression behavior; however, they displayed significantly less nonaggression social interactions than WT mice (Fig. 4G). In addition, in the resident-intruder aggression assay, $\mathrm{AC1}+$ mice were more aggressive than WT mice to intruders into their home cages; the latency of attack was 
A

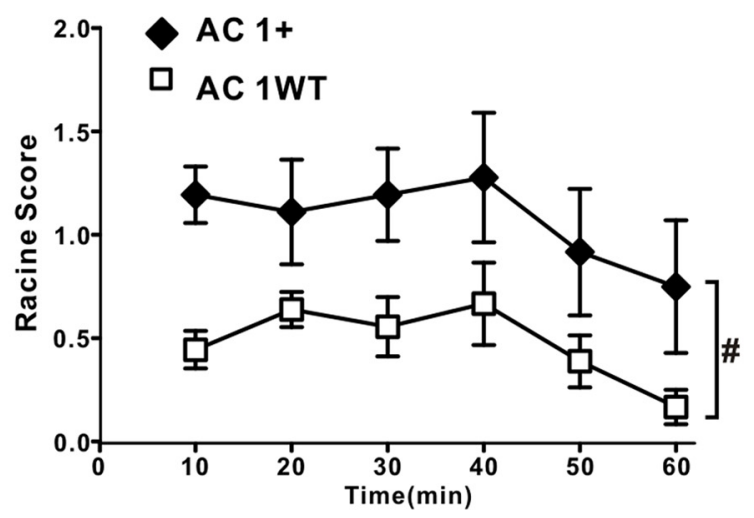

B
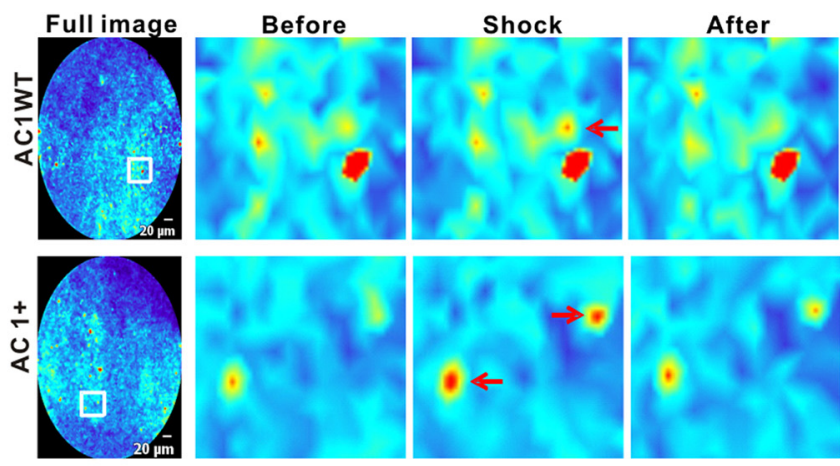

C

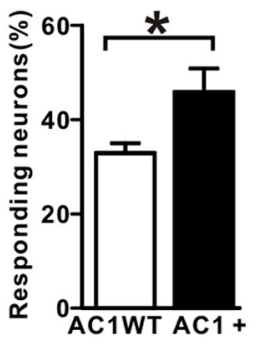

D Anti-GFP staining location of imaging site

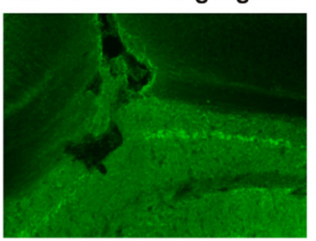

E
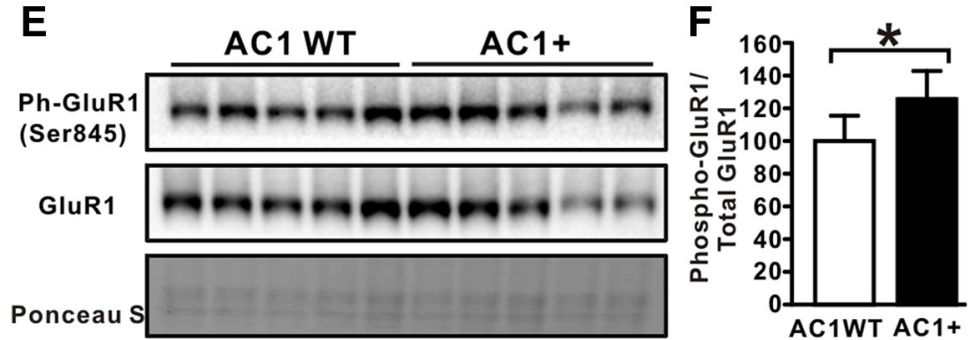

G AC1 WT AC1+
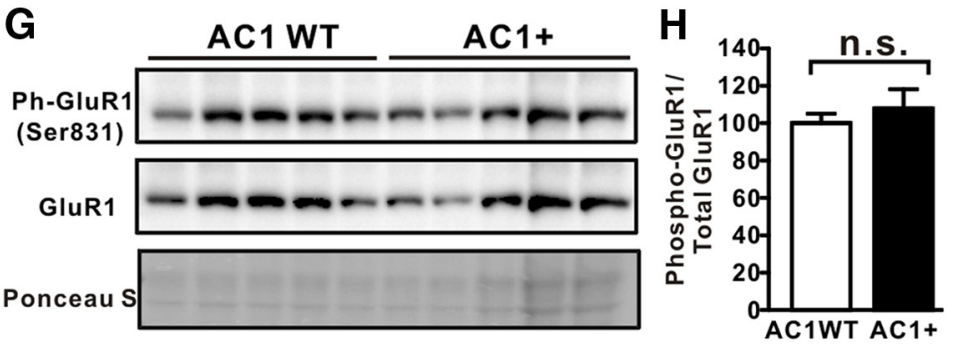

Figure 5. CA1 hippocampal neurons of $\mathrm{AC} 1+$ mice are more responsive. $A, A C 1+$ mice have more prominent epileptic activity than AC1WT mice after injection of a subepileptic dose of kainate; $n=9$ pairs, genotype effect, two-way ANOVA test; $F_{(1,80)}=$ $5.60, \# p<0.05 . B-D, C A 1$ neurons of $A C 1+$ mice show increased activation in response to foot-shock stimulation during training for contextual fear memory. $\boldsymbol{B}$, In vivo calcium image. Left, Representative whole-field images of CA1 region under free-behaving mice using FFE. Right, Enlarged views of selected regions of interest (Brechbühl et al., 2013), which show cell bodies of GCaMP6expressing neurons in CA1 regions. Representative images of before, during, and after foot shock. $C$, The percentage of neurons responding to foot shock was increased in $\mathrm{AC} 1+$ mice. Neurons with calcium spikes upon a foot shock were counted as responding shorter for AC1 + mice than WT controls (Fig. 4H). In contrast, AC1/8 DKO mice had longer latency to attack the intruder than WT mice (Fig. 4I). AC1 + mice have normal olfactory function as demonstrated in a habituation/dishabituation test using various odorants (Fig. $4 J$ ). Collectively, these data indicate that $\mathrm{AC} 1+$ mice have a significant social dysfunction.

CA1 neurons of AC1 + mice demonstrate increased activation

We reasoned that overexpressing $\mathrm{AC} 1$ may increase neuronal activity by robust synaptic transmission caused by increased LTP (Wang et al., 2004) and impaired LTD (Wang and Zhang, 2012; Zhang and Wang, 2013). To test whether neurons in the brain of $\mathrm{AC} 1+$ mice are more responsive, we administered an epileptic agent, kainate $(10 \mathrm{mg} / \mathrm{kg}$, subepilepsy threshold dose), into both WT and $\mathrm{AC} 1+$ mice and examined seizure-like behaviors. AC1+ mice displayed more epileptic activity than WT mice after injection of a low dose of kainate (Fig. 5A), indicating that AC1+ mice are more sensitive to kainate acid. This suggests that neurons of $\mathrm{ACl}+$ mice are more responsive to stimulation. To determine whether CA1 neurons of $\mathrm{AC} 1+$ mice are more responsive in vivo than $\mathrm{WT}$ mice to stimulation, we used FFE to perform deep-brain calcium imaging when mice were trained for contextual fear memory (Vincent et al., 2006). We virally delivered a genetically encoded calcium indicator, GCaMP6 into the CA1 region of AC1 WT and $\mathrm{AC} 1+$ mice (Fig. $5 B-D$ ). We then inserted a fiber fluorescence probe through a cannula to monitor the activity of CA1 neurons. FFE monitored the level of intracellular free calcium in the cell body of GCaMP6-expressing neurons in free-behaving mice (Fig. 5B). Upon foot-shock stimulation, the percentage of responding neurons in area CA1 (imaging

$\leftarrow$

neurons; $n=5$ pairs of mice, $12-36$ neurons from each mouse were analyzed; * $p<0.05$. D, Representative image of CA1 neurons of AC1 + mice stained with anti-GFP antibody (green, recognizing the G(aMP6). Only the hippocampal CA1 was infected with AAV1. The damaged tissue denotes track made by inserting imaging probe. $\boldsymbol{E}-\boldsymbol{H}$, Increased basal phosphorylation level of GluR1 of AMPA receptors at the $\mathrm{p} 845$ site $(\boldsymbol{E}, \boldsymbol{F})$ but not at the p831 site $(\boldsymbol{G}, \boldsymbol{H})$ in the hippocampus of $A C 1+$ mice. Hippocampal lysates obtained from WT and AC1 + mice were probed for anti-GluR1 phosphorylation (anti-p-Ser845 and anti-p-Ser831 respectively) and total GluR1 levels respectively by Western blot analysis. Bar graph shows the quantification of the phospho-GluR1/GluR1 levels in wild-type littermates and $A C 1+$ and is expressed as a percentage of WT littermates; $n=5$ pairs; ${ }^{*} p<0.05 ;$ n.s., not significant. 
A
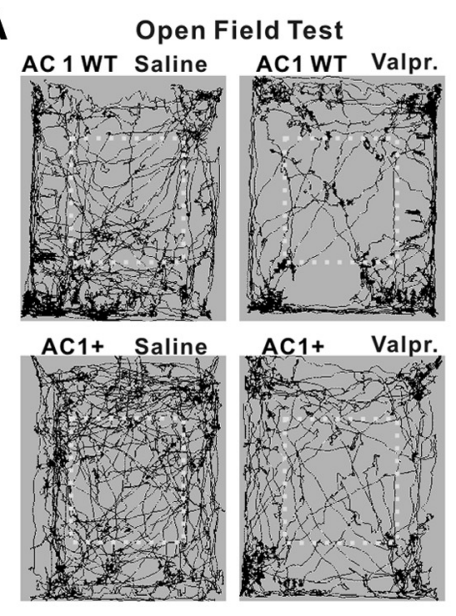

C

Elevated Plus Maze
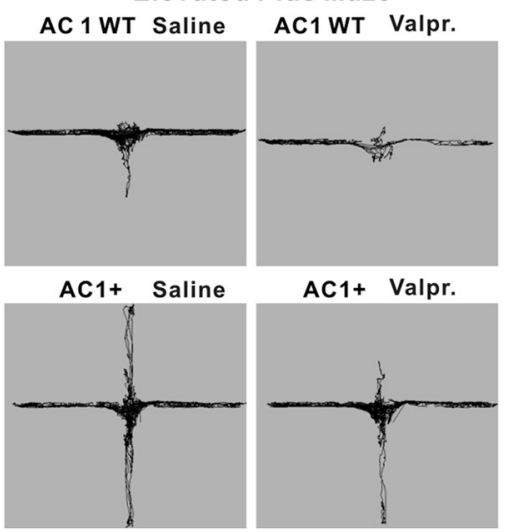

E

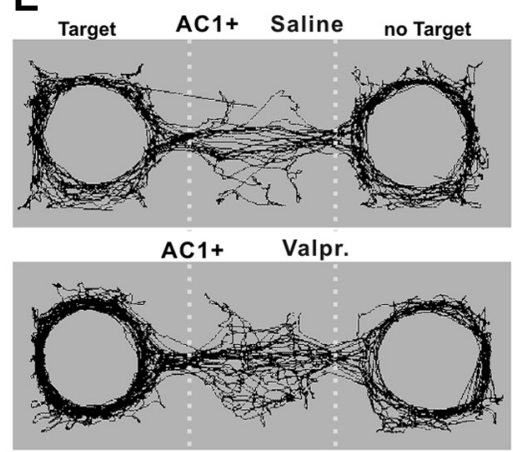

G

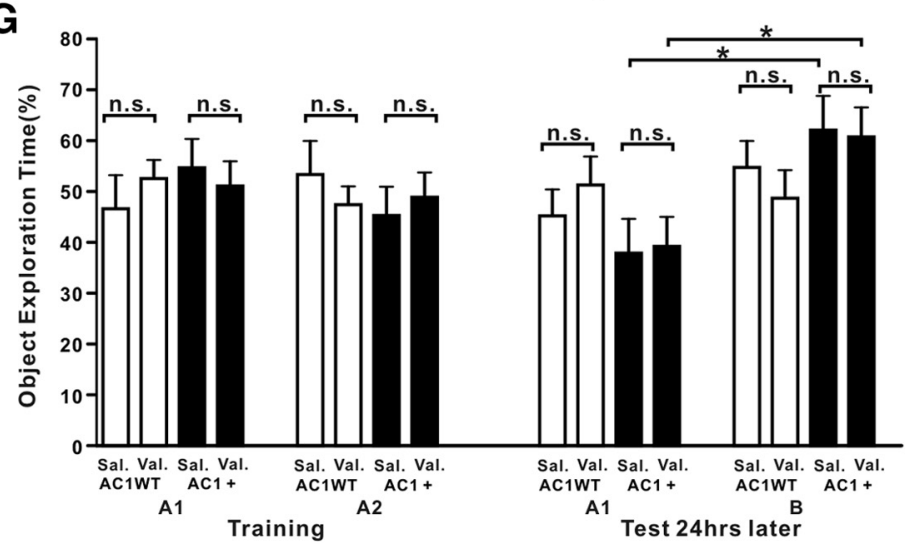

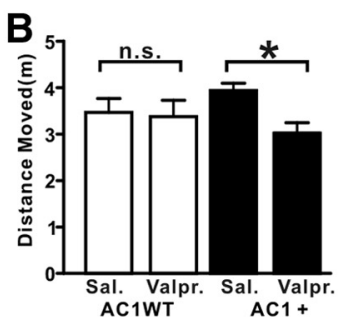
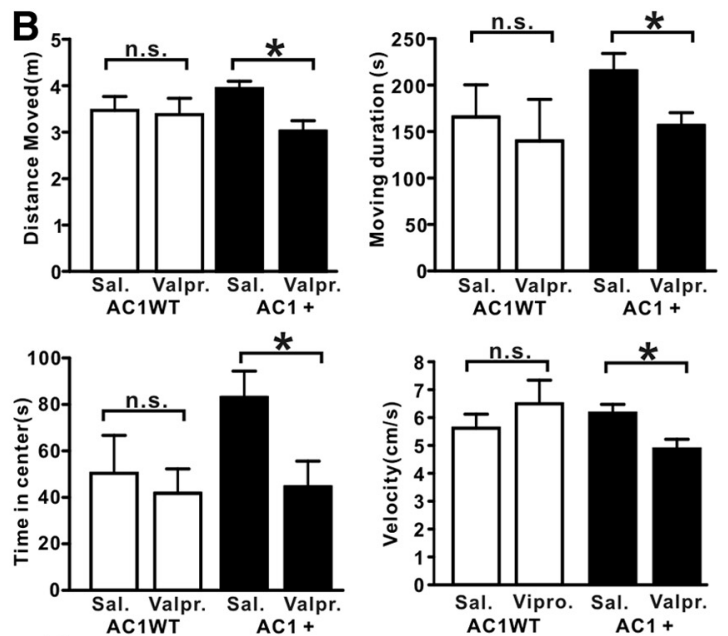

D
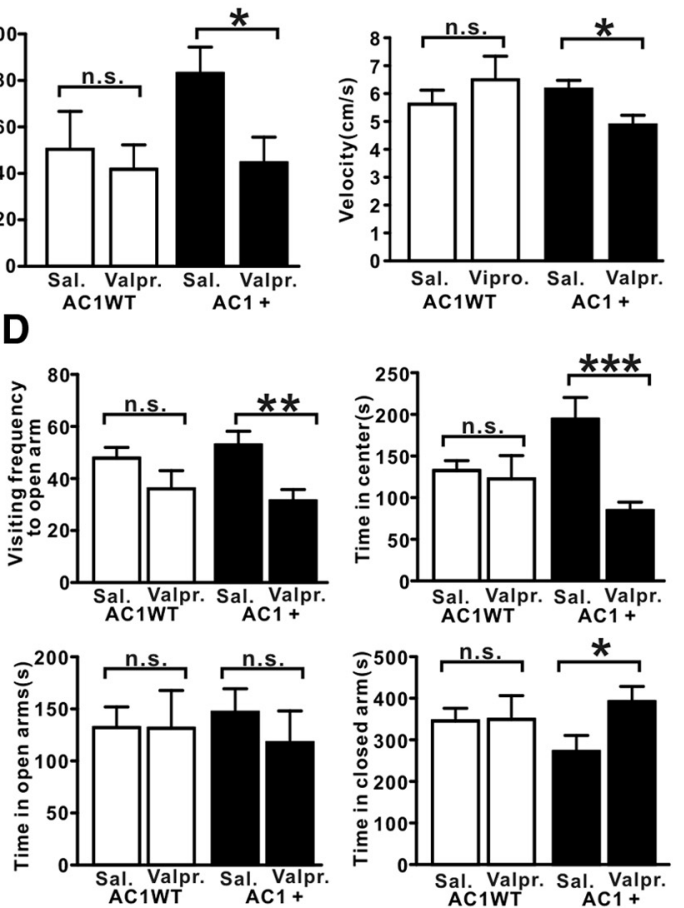

$\mathbf{F}$

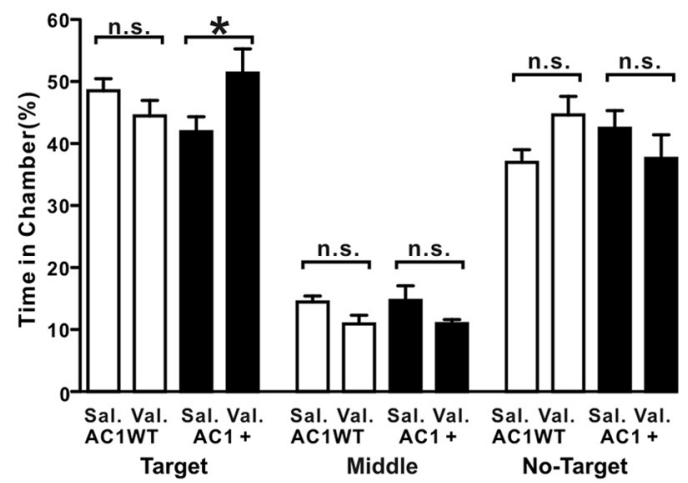

No-Target 
A

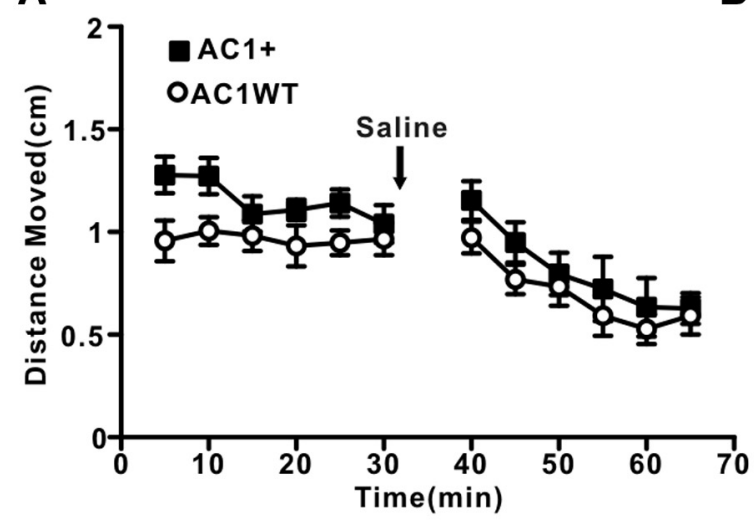

B

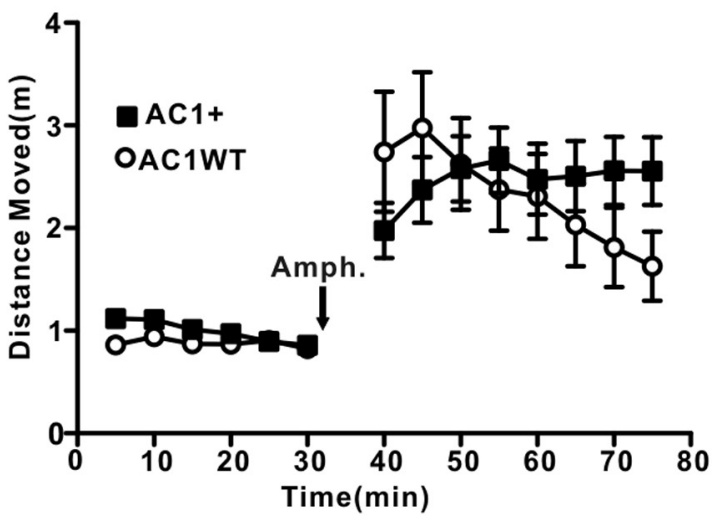

Figure 7. Amphetamine does not suppress the hyperactivity of AC1 + mice in an open field. Mice explored in an open field for 20 min before drug or saline treatment. The distance moved in an open field was plotted against exploration time before and after treatment. $\boldsymbol{A}$, Saline-treated; $n=7 \mathrm{WT} ; n=7 \mathrm{AC} 1+$ mice. $\boldsymbol{B}$, Amphetamine-treated $(4 \mathrm{mg} / \mathrm{kg}, \mathrm{i} . \mathrm{p}$.); $n=10 \mathrm{WT} ; n=10 \mathrm{AC} 1+$ mice. Genotype effect: $F_{(1,126)}=0.03, p=0.87$, repeated-measure, two-way ANOVA of data of post-treatment.

location shown in Fig. 5D) of AC1+ mice was greater than WT control mice (Fig. 5C). These data confirm that CA1 neurons of $\mathrm{AC} 1+$ mice are more active than WT mice.

Because $\mathrm{AC} 1+$ mice have increased cAMP and PKA activity in the brain (Wang et al., 2004), we examined the basal level of phosphorylation of the GluR1 subunit in AMPA receptors at Ser-845 (a PKA recognition site) and Ser-831 (a PKC and CaMKII recognition site; Shukla et al., 2007) in plasma membrane-enriched fractions of hippocampi from WT and $\mathrm{AC} 1+$ mice. Western blot analysis of hippocampal membrane fractions revealed a significant increase in basal phosphorylation at GluR1 Ser-845 in AC1+ mice compared with WT mice (Fig. $5 E, F)$. However, hippocampal GluR1 Ser-831 phosphorylation did not display any significant difference between WT and AC1+ mice (Fig. 5G,H). Increased phosphorylation of GluR1 at Ser 845 of AMPA receptors enhances receptors conductance and membrane trafficking (Shukla et al., 2007). The increased activation of AMPA receptors is in line with the hyperactivity observed in $\mathrm{AC} 1+$ mice. These data are also consistent with the role of $\mathrm{AC} 1$ in synaptic plasticity (Wang and Zhang, 2012; Zhang and Wang, 2013).

\section{Valproate decreases the hyperactivity and exploration activity of} AC1 + mice

The hyperactivity of $\mathrm{ACl}+$ mice is presumably caused by increased level of adenylyl cyclase, thus we tested whether val-

\footnotetext{
$\leftarrow$

Figure 6. Valproate reduces the hyperactive behaviors of $\mathrm{AC} 1+$ mice. $A, \boldsymbol{B}$, Valproate reduced the hyperactivity of $\mathrm{AC} 1+$ mice in the open- field test. $A$, Representative exploratory tracks. $\boldsymbol{B}$, The distance moved, the moving duration, time in the center, and moving velocity in $\mathrm{AC} 1+$ mice were decreased by valproate; $n=7-10 ;{ }^{*} p<0.05 ;$ n.s., not significant. C, $\boldsymbol{D}$, Valproate reduced the exploration activity of $\mathrm{AC} 1+$ mice in the open arm in the elevated plus test. $\boldsymbol{C}$, Representative exploratory tracks in the elevated plus maze. $\boldsymbol{D}$, The frequency visiting the open arm, the time in the center of $\mathrm{AC} 1+$ mice were significantly decreased, whereas the time in the closed arm of $\mathrm{AC} 1+$ mice were increased by valproate; $n=7-11 ;{ }^{*} p<0.05$, ${ }^{* *} p<0.01 ;{ }^{* * *} p<0.001 . \boldsymbol{E}, \boldsymbol{F}$, Valproate slightly increased the sociability of AC1 + mice. $\boldsymbol{E}$, Representative exploratory tracks of AC1 + mice injected with saline or with valproate in threechamber sociability test. $\boldsymbol{F}$, Percentage of time in each chamber. After valproate treatment, $\mathrm{AC} 1+$ mice spent more time to interact with target mouse than $\mathrm{AC} 1+$ mice injected with saline; $n=7-9 ;{ }^{*} p<0.05 ; n$.s., not significant by unpaired Student's $t$ test. G, Valproate does not affect the recognition memory of $\mathrm{AC} 1+$ mice in the novel-object recognition test. Mice were trained on day 1 for object $A 1$ and $A 2$, tested $1 \mathrm{~h}$ later for object $A 1$ and $B(1 \mathrm{~h}$ data not shown), and retested $24 \mathrm{~h}$ later for object $\mathrm{A} 1$ and $\mathrm{B}$. $\mathrm{AC} 1+$ and WT mice are treated with saline or valproate respectively before experiment; $n=5-9 ;$ n.S., not significant; ${ }^{*} p<0.05$.
}

proate, a mood-stabilizing drug that can decrease intracellular cAMP (Gould et al., 2004; Chiu et al., 2013), corrects the behavioral abnormalities of $\mathrm{AC} 1+$ mice. Valproate decreases cAMP levels in the brain (Chen et al., 1996; Gould et al., 2004; Chiu et al., 2013) probably by stimulating cAMP phosphodiesterase activity (Gallagher et al., 2004). In the open-field test, valproate decreased locomotor hyperactivity of $\mathrm{ACl}+$ mice to levels comparable with WT mice. The distance moved, the moving duration, time in the center and moving velocity of $\mathrm{AC} 1+$ mice were all decreased by valproate (Fig. $6 A, B$ ). In the elevated plus maze test, valproate suppressed exploratory behavior of AC1 + mice in the open arm. After injection of valproate, the visiting frequency to the open arm, the time in the center of $\mathrm{ACl}+$ mice were strongly decreased, while the time in closed arm was increased (Fig. 6C,D). These data indicates that valproate mitigates the hyperactive behavior of $\mathrm{AC} 1+$ mice. Moreover, the sociability of $\mathrm{AC} 1+$ mice was slightly increased by valproate (Fig. $6 E, F$ ). These data indicate that the hyperactivity and reduced sociability of $\mathrm{AC} 1+$ mice can be corrected at least in part by valproate.

Overexpression of $\mathrm{AC} 1$ in the forebrain enhances recognition memory (Wang et al., 2004). Therefore, we tested whether valproate affects the novel-object recognition memory of the $\mathrm{AC} 1+$ mice. We found that both WT and AC1 + mice spent comparable times with each object during the training period, which was not changed by saline or valproate treatment. One of the original objects (A2) was replaced by a new object (B) $1 \mathrm{~h}$ after training. Both WT and AC1+ mice with either saline or valproate injection spent more time with the new object, indicating similar recognition memory $1 \mathrm{~h}$ after training. After $24 \mathrm{~h}$, WT mice spent approximately similar time with each object no matter saline or valproate treatment. However, AC1 + mice still spent much more time exploring the object B $24 \mathrm{~h}$ after training with saline or valproate injection (Fig. $6 G$ ). These results confirm that $\mathrm{AC} 1+$ mice have stronger memory than WT mice and valproate does not suppress the recognition memory of $\mathrm{AC} 1+$ mice.

$\mathrm{ACl}+$ mice exhibit hyperactive and impulsive behaviors, seemingly recapitulating endophenotypes of the predominantly hyperactive-impulsive subtype of human attention-deficit and hyperactive disorder (ADHD; Williams et al., 1999; Wolraich et al., 2005). To assess whether AC1+ mice is a mouse model for studying human $\mathrm{ADHD}$, we treated $\mathrm{AC} 1+$ mice with amphetamine, a primary ADHD medicine. Amphetamine, as a psychostimulant for normal subjects, paradoxically suppresses the 
hyperactivity of ADHD patients and ADHD animal models (Avale et al., 2004; Spencer, 2004). We found that amphetamine treatment $(4 \mathrm{mg} / \mathrm{kg}$, i.p.) increases the locomotor activity of both $\mathrm{WT}$ and $\mathrm{AC} 1+$ mice. Although the effect of amphetamine on $\mathrm{AC} 1+$ mice is slightly different from that of WT mice, the data clearly demonstrate that amphetamine does not suppressed hyperactivity of $\mathrm{AC} 1+$ mice (Fig. 7). This result suggests that although $\mathrm{ACl}+$ mice demonstrate hyperactivity/impulsivity phenotypes, they are not a mouse model for studying human ADHD.

\section{Discussion}

In this study, we report that overexpression of AC1 in the forebrain of mice causes hyperactive and impulsive behaviors, as well as reduced sociability. In contrast, $\mathrm{AC} 1 / 8 \mathrm{DKO}$ mice are hypoactive and exhibit increased sociability and reduced impulsivity. We also present evidence that the hyperactivity of $\mathrm{AC} 1+$ mice can be reduced by valproate.

\section{$\mathrm{AC} 1+$ mice are hyperactive and lack behavioral inhibition}

One of the most striking phenotypes exhibited by $\mathrm{AC} 1+$ mice are hyperactivity and lack of behavioral inhibition. AC1 + mice exhibited reduced anxiety when submitted to several behavioral paradigms. For example, in the elevated plus maze $\mathrm{AC} 1+$ spent more time in the open arm which indicates that they were much less anxious than WT mice about the risk of falling from the open arm. In the open-field test, $\mathrm{AC} 1+$ mice were less anxious and actively explored the open field. Moreover, when a novel object was put on the center of the open field, $\mathrm{AC} 1+$ mice investigated it much more frequently than WT mice. All of these behaviors indicate less concern about potentially risky behavior. When $\mathrm{ACl}+$ mice were exposed to TMT, an odor signal suggesting the presence of a predator, they did not tend to avoid TMT, indicating that $\mathrm{AC} 1+$ mice may not attentive to possible risks.

In the CAR test, a test for impulsivity (Matsuoka et al., 2005; Kuroda et al., 2011; Yamashita et al., 2013), AC1 + mice are more active than WT mice and examined the cliff more frequently than WT mice. This risk-taking behavior led to more falls from the platform. In addition, in the resident/intruder aggression assay, $\mathrm{AC} 1+$ resident mice have shorter latency to attack a male intruder than WT mice. Collectively, AC1 + mice demonstrate deficits of behavioral inhibition. The phenotypes of $\mathrm{AC} 1+$ mice are in agreement with the molecular features of AC1. AC1 is stimulated by activity-dependent calcium increases which cause synaptic potentiation and increased neuronal activity (Villacres et al., 1998; Wong et al., 1999; Wei et al., 2002; Wang et al., 2004). We postulate that increased levels of AC1 in the forebrain of $\mathrm{AC} 1+$ mice probably overamplify intracellular calcium signals.

The mechanism for the hyperactivity/impulsivity of $\mathrm{AC} 1+$ mice is not clear. One plausible explanation would be that increasing AC1 activity leads to enhanced cAMP signaling and increased synaptic activity. At the synaptic level, cAMP is known to modulate several neuronal targets, including transmitter receptors and transcription factors that ultimately lead to new gene expression and protein synthesis (Xia and Storm, 2005). The cAMP-signal transduction system directly or indirectly influences long-term changes in synaptic transmission including LTP. Here we also present supporting evidence that phosphorylation of GluR1 at Ser 845 of AMPA receptors is amplified when AC1 activity is increased. AC1 is the prominent form of calciumstimulated adenylyl cyclase expressed specifically in the nervous system and it plays crucial role in synaptic plasticity. AC1/8 DKO mice have impaired LTP throughout the CNS (Villacres et al.,
1998; Wong et al., 1999). In contrast, increased AC1 expression in $\mathrm{AC} 1+$ mice facilitates LTP in the hippocampus (Wang et al., 2004). More interestingly, AC1 + mice do not show LTD at the hippocampal Shaffer collateral-CA1 synapses (Wang and Zhang, 2012; Zhang and Wang, 2013), suggesting that increased AC1 causes inhibition of synaptic depression. Therefore, we propose that increased AC1 expression may alter the excitation/inhibition balance in the brain thereby promoting LTP and inhibiting LTD, which may consequently cause hyperactivity/ impulsivity in behaviors.

\section{Sociability is reduced in AC1 + mice}

$\mathrm{AC} 1+$ mice were also submitted to a set of social behavioral tests including the three-chamber sociability test, social-choice test, reciprocal interaction test, and the resident-intruder aggression test. In the three-chamber sociability test, social choice test, and reciprocal interaction test, $\mathrm{ACl}+$ mice spent significant less time than controls in interacting with the target mouse. In addition, $\mathrm{AC} 1+$ mice are more aggressive toward a home intruder than WTs. However, AC1 + mice exhibit normal olfaction. These results indicate although $\mathrm{AC} 1+$ mice are more active, they are less social. Interestingly, $\mathrm{AC1} / 8 \mathrm{DKO}$ mice spend more time interacting with conspecifics and are less aggressive. Collectively these data suggest that increasing calcium-stimulated adenylyl cyclase in the brain enhances memory but it decreases sociability.

Because mice lacking calmodulin-stimulated adenylyl cyclases cannot form long-term memory (Villacres et al., 1998; Wong et al., 1999) and AC1 is neurospecific (Xia et al., 1993), drugs that enhance $\mathrm{ACl}$ activity have the potential to enhance memory. Indeed, $\mathrm{AC} 1+$ mice have superior memory compared with WT mice (Wang et al., 2004). However, the data reported in this study introduces a cautionary note. Drugs that increase the activity of AC1 may have serious side effects including hyperactivity, impulsivity, and social dysfunction. Therefore, attempts to increase memory using any drug that increase cAMP signaling in the brain by stimulating adenylyl cyclase activity or inhibiting cAMP phosphodiesterase activity have the potential to cause impulsivity or impaired behavioral inhibition.

\section{References}

Arnsten AF, Jin LE (2012) Guanfacine for the treatment of cognitive disorders: a century of discoveries at Yale. Yale J Biol Med 85:45-58. Medline

Avale ME, Falzone TL, Gelman DM, Low MJ, Grandy DK, Rubinstein M (2004) The dopamine D4 receptor is essential for hyperactivity and impaired behavioral inhibition in a mouse model of attention deficit/hyperactivity disorder. Mol Psychiatry 9:718-726. CrossRef Medline

Brechbühl J, Moine F, Klaey M, Nenniger-Tosato M, Hurni N, Sporkert F, Giroud C, Broillet MC (2013) Mouse alarm pheromone shares structural similarity with predator scents. Proc Natl Acad Sci U S A 110:47624767. CrossRef Medline

Chen G, Manji HK, Wright CB, Hawver DB, Potter WZ (1996) Effects of valproic acid on beta-adrenergic receptors, G-proteins, and adenylyl cyclase in rat C6 glioma cells. Neuropsychopharmacology 15:271-280. CrossRef Medline

Chiu CT, Wang Z, Hunsberger JG, Chuang DM (2013) Therapeutic potential of mood stabilizers lithium and valproic acid: beyond bipolar disorder. Pharmacol Rev 65:105-142. CrossRef Medline

Choi EJ, Wong ST, Hinds TR, Storm DR (1992) Calcium and muscarinic agonist stimulation of type I adenylylcyclase in whole cells. J Biol Chem 267:12440-12442. Medline

Cross-Disorder Group of the Psychiatric Genomics Consortium (2013) Identification of risk loci with shared effects on five major psychiatric disorders: a genome-wide analysis. Lancet 381:1371-1379. CrossRef Medline

DiRocco DP, Scheiner ZS, Sindreu CB, Chan GC, Storm DR (2009) A role for calmodulin-stimulated adenylyl cyclases in cocaine sensitization. J Neurosci 29:2393-2403. CrossRef Medline 
Eckel-Mahan KL, Phan T, Han S, Wang H, Chan GC, Scheiner ZS, Storm DR (2008) Circadian oscillation of hippocampal MAPK activity and cAmp: implications for memory persistence. Nat Neurosci 11:1074-1082. CrossRef Medline

Fromer M, Pocklington AJ, Kavanagh DH, Williams HJ, Dwyer S, Gormley P, Georgieva L, Rees E, Palta P, Ruderfer DM, Carrera N, Humphreys I, Johnson JS, Roussos P, Barker DD, Banks E, Milanova V, Grant SG, Hannon E, Rose SA, et al. (2014) De novo mutations in schizophrenia implicate synaptic networks. Nature 506:179-184. CrossRef Medline

Gallagher HC, Bacon CL, Odumeru OA, Gallagher KF, Fitzpatrick T, Regan CM (2004) Valproate activates phosphodiesterase-mediated cAMP degradation: relevance to $\mathrm{C} 6$ glioma $\mathrm{G}_{1}$ phase progression. Neurotoxicol Teratol 26:73-81. CrossRef Medline

Gould TD, Quiroz JA, Singh J, Zarate CA, Manji HK (2004) Emerging experimental therapeutics for bipolar disorder: insights from the molecular and cellular actions of current mood stabilizers. Mol Psychiatry 9:734755. CrossRef Medline

Han K, Holder JL Jr, Schaaf CP, Lu H, Chen H, Kang H, Tang J, Wu Z, Hao S, Cheung SW, Yu P, Sun H, Breman AM, Patel A, Lu HC, Zoghbi HY (2013) SHANK3 overexpression causes manic-like behaviour with unique pharmacogenetic properties. Nature 503:72-77. CrossRef Medline

Krishnan V, Graham A, Mazei-Robison MS, Lagace DC, Kim KS, Birnbaum S, Eisch AJ, Han PL, Storm DR, Zachariou V, Nestler EJ (2008) Calcium-sensitive adenylyl cyclases in depression and anxiety: behavioral and biochemical consequences of isoform targeting. Biol Psychiatry 64: 336-343. CrossRef Medline

Kuroda K, Yamada S, Tanaka M, Iizuka M, Yano H, Mori D, Tsuboi D, Nishioka T, Namba T, Iizuka Y, Kubota S, Nagai T, Ibi D, Wang R, Enomoto A, Isotani-Sakakibara M, Asai N, Kimura K, Kiyonari H, Abe T, et al. (2011) Behavioral alterations associated with targeted disruption of exons 2 and 3 of the Discl gene in the mouse. Hum Mol Genet 20: 4666-4683. CrossRef Medline

Matsuoka Y, Furuyashiki T, Yamada K, Nagai T, Bito H, Tanaka Y, Kitaoka S, Ushikubi F, Nabeshima T, Narumiya S (2005) Prostaglandin E receptor EP1 controls impulsive behavior under stress. Proc Natl Acad Sci US A 102:16066-16071. CrossRef Medline

Racine RJ (1972) Modification of seizure activity by electrical stimulation: II. Motor seizure. Electroencephalogr Clin Neurophysiol 32:281-294. CrossRef Medline

Schaefer ML, Wong ST, Wozniak DF, Muglia LM, Liauw JA, Zhuo M, Nardi A, Hartman RE, Vogt SK, Luedke CE, Storm DR, Muglia LJ (2000) Altered stress-induced anxiety in adenylyl cyclase type VIII-deficient mice. J Neurosci 20:4809-4820. Medline

Shan Q, Chan GC, Storm DR (2008) Type 1 adenylyl cyclase is essential for maintenance of remote contextual fear memory. J Neurosci 28:1286412867. CrossRef Medline

Shukla K, Kim J, Blundell J, Powell CM (2007) Learning-induced glutamate receptor phosphorylation resembles that induced by long term potentiation. J Biol Chem 282:18100-18107. CrossRef Medline

Sindreu CB, Scheiner ZS, Storm DR (2007) Ca2+-stimulated adenylyl cyclases regulate ERK-dependent activation of MSK1 during fear conditioning. Neuron 53:79-89. CrossRef Medline

Soden ME, Jones GL, Sanford CA, Chung AS, Güler AD, Chavkin C, Luján R, Zweifel LS (2013) Disruption of dopamine neuron activity pattern regulation through selective expression of a human KCNN3 mutation. Neuron 80:997-1009. CrossRef Medline

Spencer TJ (2004) ADHD treatment across the life cycle. J Clin Psychiatry 65:22-26. CrossRef Medline

Tabuchi K, Blundell J, Etherton MR, Hammer RE, Liu X, Powell CM, Südhof TC (2007) A neuroligin-3 mutation implicated in autism increases inhibitory synaptic transmission in mice. Science 318:71-76. CrossRef Medline

Villacres EC, Wong ST, Chavkin C, Storm DR (1998) Type I adenylyl cyclase mutant mice have impaired mossy fiber long-term potentiation. J Neurosci 18:3186-3194. Medline

Vincent P, Maskos U, Charvet I, Bourgeais L, Stoppini L, Leresche N, Chan- geux JP, Lambert R, Meda P, Paupardin-Tritsch D (2006) Live imaging of neural structure and function by fibred fluorescence microscopy. EMBO Reports 7:1154-1161. CrossRef Medline

Wang H, Storm DR (2003) Calmodulin-regulated adenylyl cyclases: crosstalk and plasticity in the central nervous system. Mol Pharmacol 63:463468. CrossRef Medline

Wang H, Zhang M (2012) The role of Ca(2)(+)-stimulated adenylyl cyclases in bidirectional synaptic plasticity and brain function. Rev Neurosci 23:67-78. CrossRef Medline

Wang H, Ferguson GD, Pineda VV, Cundiff PE, Storm DR (2004) Overexpression of type- 1 adenylyl cyclase in mouse forebrain enhances recognition memory and LTP. Nat Neurosci 7:635-642. CrossRef Medline

Wang H, Xu H, Wu LJ, Kim SS, Chen T, Koga K, Descalzi G, Gong B, Vadakkan KI, Zhang X, Kaang BK, Zhuo M (2011) Identification of an adenylyl cyclase inhibitor for treating neuropathic and inflammatory pain. Science Transl Med 3:65ra3. CrossRef Medline

Wang Z, Balet Sindreu C, Li V, Nudelman A, Chan GC, Storm DR (2006) Pheromone detection in male mice depends on signaling through the type 3 adenylyl cyclase in the main olfactory epithelium. J Neurosci 26:73757379. CrossRef Medline

Wayman GA, Impey S, Wu Z, Kindsvogel W, Prichard L, Storm DR (1994) Synergistic activation of the type I adenylyl cyclase by Ca2+ and Gscoupled receptors in vivo. J Biol Chem 269:25400-25405. Medline

Wei F, Qiu CS, Kim SJ, Muglia L, Maas JW, Pineda VV, Xu HM, Chen ZF, Storm DR, Muglia LJ, Zhuo M (2002) Genetic elimination of behavioral sensitization in mice lacking calmodulin-stimulated adenylyl cyclases. Neuron 36:713-726. CrossRef Medline

Wieczorek L, Majumdar D, Wills TA, Hu L, Winder DG, Webb DJ, Muglia LJ (2012) Absence of Ca2+-stimulated adenylyl cyclases leads to reduced synaptic plasticity and impaired experience-dependent fear memory. Transl Psychiatry 2:e126. CrossRef Medline

Williams C, Wright B, Partridge I (1999) Attention deficit hyperactivity disorder: a review. Br J Gen Pract 49:563-571. Medline

Wolf EJ, Rasmusson AM, Mitchell KS, Logue MW, Baldwin CT, Miller MW (2014) A genome-wide association study of clinical symptoms of dissociation in a trauma-exposed sample. DepresS Anxiety 31:352-360. CrossRef Medline

Wolraich ML, Wibbelsman CJ, Brown TE, Evans SW, Gotlieb EM, Knight JR, Ross EC, Shubiner HH, Wender EH, Wilens T (2005) Attention-deficit/ hyperactivity disorder among adolescents: a review of the diagnosis, treatment, and clinical implications. Pediatrics 115:1734-1746. CrossRef Medline

Wong ST, Athos J, Figueroa XA, Pineda VV, Schaefer ML, Chavkin CC, Muglia LJ, Storm DR (1999) Calcium-stimulated adenylyl cyclase activity is critical for hippocampus-dependent long-term memory and late phase LTP. Neuron 23:787-798. CrossRef Medline

Wu ZL, Thomas SA, Villacres EC, Xia Z, Simmons ML, Chavkin C, Palmiter $\mathrm{RD}$, Storm DR (1995) Altered behavior and long-term potentiation in type I adenylyl cyclase mutant mice. Proc Natl Acad Sci U S A 92:220224. CrossRef Medline

Xia Z, Storm DR (2005) The role of calmodulin as a signal integrator for synaptic plasticity. Nat Rev Neurosci 6:267-276. CrossRef Medline

Xia ZG, Refsdal CD, Merchant KM, Dorsa DM, Storm DR (1991) Distribution of mRNA for the calmodulin-sensitive adenylate cyclase in rat brain: expression in areas associated with learning and memory. Neuron 6:431443. CrossRef Medline

Xia Z, Choi EJ, Wang F, Blazynski C, Storm DR (1993) Type I calmodulinsensitive adenylyl cyclase is neural specific. J Neurochem 60:305-311. CrossRef Medline

Yamashita M, Sakakibara Y, Hall FS, Numachi Y, Yoshida S, Kobayashi H, Uchiumi O, Uhl GR, Kasahara Y, Sora I (2013) Impaired cliff avoidance reaction in dopamine transporter knockout mice. Psychopharmacology 227:741-749. CrossRef Medline

Zhang M, Wang H (2013) Mice overexpressing type 1 adenylyl cyclase show enhanced spatial memory flexibility in the absence of intact synaptic longterm depression. Learn Mem 20:352-357. CrossRef Medline 